\title{
The short-term combined effects of temperature and organic matter enrichment on permeable coral reef carbonate sediment metabolism and dissolution
}

\author{
Coulson A. Lantz, Kai G. Schulz, Laura Stoltenberg, and Bradley D. Eyre \\ Centre for Coastal Biogeochemistry, School of Environment, Science, and Engineering, Military Road Southern \\ Cross University, Lismore 2480 NSW, Australia \\ Correspondence to: Coulson A. Lantz (coulsonlantz@gmail.com)
}

Received: 30 March 2017 - Discussion started: 28 April 2017

Revised: 11 September 2017 - Accepted: 28 September 2017 - Published: 1 December 2017

\begin{abstract}
Rates of gross primary production (GPP), respiration $(R)$, and net calcification $\left(G_{\text {net }}\right)$ in coral reef sediments are expected to change in response to global warming (and the consequent increase in sea surface temperature) and coastal eutrophication (and the subsequent increase in the concentration of organic matter, OM, being filtered by permeable coral reef carbonate sediments). To date, no studies have examined the combined effect of seawater warming and OM enrichment on coral reef carbonate sediment metabolism and dissolution. This study used $22 \mathrm{~h}$ in situ benthic chamber incubations to examine the combined effect of temperature $(T)$ and $\mathrm{OM}$, in the form of coral mucus and phytodetritus, on GPP, $R$, and $G_{\text {net }}$ in the permeable coral reef carbonate sediments of Heron Island lagoon, Australia. Compared to control incubations, both warming $\left(+2.4{ }^{\circ} \mathrm{C}\right)$ and $\mathrm{OM}$ increased $R$ and GPP. Under warmed conditions, $R\left(Q_{10}=10.7\right)$ was enhanced to a greater extent than GPP $\left(Q_{10}=7.3\right)$, resulting in a shift to net heterotrophy and net dissolution. Under both phytodetritus and coral mucus treatments, GPP was enhanced to a greater extent than $R$, resulting in a net increase in GPP / $R$ and $G_{\text {net }}$. The combined effect of warming and OM enhanced $R$ and GPP, but the net effect on GPP / $R$ and $G_{\text {net }}$ was not significantly different from control incubations. These findings show that a shift to net heterotrophy and dissolution due to short-term increases in seawater warming may be countered by a net increase GPP / $R$ and $G_{\text {net }}$ due to short-term increases in nutrient release from OM.
\end{abstract}

\section{Introduction}

Despite occupying only $7.5 \%$ of the seafloor, coastal marine sediments are responsible for a large fraction $(55 \%)$ of global sediment organic matter oxidation (Middelburg et al., 1997). Of the coastal marine sediment environments, coral reef sediments are one of the most severely threatened by global climate change (Halpern et al., 2007). Rates of sediment autotrophic production (gross primary productivity; GPP) on coral reefs are generally greater than rates of heterotrophic metabolism (respiration; $R$; GPP / $R>1$ ), such that the sediments are a net source of oxygen (Atkinson, 2011). Similarly, rates of sediment calcification/precipitation are generally greater than rates of sediment dissolution $\left(G_{\text {net }}>0\right)$ on most reefs under current ocean conditions, such that coral reef sediments on diel $(24 \mathrm{~h})$ timescales are net precipitating, resulting in the long-term burial of carbon in the form of calcium carbonate (Eyre et al., 2014; Andersson, 2015). This long-term production of calcium carbonate is an important component of reef formation and the creation of sandy cays (Atkinson, 2011). However, due to anthropogenically mediated processes such as sea surface temperature (SST) warming (Levitus et al., 2000) and coastal eutrophication (Fabricius, 2005), coral reef sediments may soon be subjected to elevated SSTs and excess loadings of OM (Rabouille et al., 2001). This could ultimately impact the balance in GPP / $R$ and $G_{\text {net }}$ in the sediment and potentially alter the long-term accumulation of carbonate material on coral reefs (Orlando and Yee, 2016).

Given the recent projections of SST increases on coral reefs of between 1.2 and $3.2^{\circ} \mathrm{C}$ by the end of this century 
(IPCC, 2013), there are concerns that the net metabolic balance in coral reef sediments may shift away from net production and net calcification to a state of net heterotrophy and net dissolution (Pandolfi et al., 2011). While several coral reef studies have examined the response in individual calcifying organisms to increased seawater temperature $(T$; e.g. Johnson and Carpenter, 2012; Shaw et al., 2016), only one study (Trnovsky et al., 2016) has examined the response in entire permeable coral reef carbonate sediments. Furthermore, the majority of warming studies on marine sediments have been performed ex situ in more poleward latitudes (temperate to arctic environments) over a wide range of temperatures $\left(2-30^{\circ} \mathrm{C}\right.$; e.g. Tait and Schiel, 2013; Hancke et al., 2014; Ashton et al., 2017). The bacterial communities residing in marine sediments generally display a hyperbolic temperature-production relationship where GPP increases with $T\left(\sim+32 \%\right.$ per $1{ }^{\circ} \mathrm{C}$ increase) until an optimal rate is reached roughly $+2-3{ }^{\circ} \mathrm{C}$ above naturally observed seasonal maxima. This $T-\mathrm{GPP}$ relationship then declines at higher temperatures $\left(+4-6{ }^{\circ} \mathrm{C}\right)$ due to the deactivation of component reactions (Bernacchi et al., 2001). In Arctic and temperate marine sediment communities, the increase in $T$ can alter the balance between GPP and $R$, with an observed shift towards net heterotrophy (GPP / $R<1$; e.g. Hancke and Glud, 2004; Weston and Joye, 2005). Trnovsky et al. (2016) found that warming also decreased GPP / $R$ in coral reef sediments and reduced $G_{\text {net }}$ due to enhanced sediment dissolution.

Ultimately, the magnitude of potential shifts in coral reef sediment GPP / $R$ and $G_{\text {net }}$ under global warming scenarios will depend critically on the availability of organic matter (OM) substrate for remineralisation (Ferguson et al., 2003; Rabalais et al., 2009). Carbonate sediment dissolution is strongly controlled by the extent of OM decomposition in the sediments (Andersson, 2015). Coral reefs are classically characterised as oligotrophic, i.e. relatively deficient in major inorganic nutrients (Koop et al., 2001). Despite this classification, the relatively high rates of GPP ( 1 to $3 \mathrm{~mol} \mathrm{C} \mathrm{m}^{-2} \mathrm{~d}^{-1}$ ) for these ecosystems (Odum and Odum, 1955) are evidence of a tightly coupled nutrient cycling between autotrophs and heterotrophs. However, the balance in sediment metabolism on coral reefs may change in response to OM over-enrichment associated with eutrophication (Bell, 1992). Coral reefs affected by eutrophication (e.g. Hawaii: Grigg, 1995; Indonesia: Edinger et al., 1998; Jamaica: Mallela and Perry, 2007; Puerto Rico: Diaz-Ortega and Hernandez-Delgado, 2014) all exhibit elevated concentrations of OM in the water column (particulate OM: 10$\left.50 \mu \mathrm{mol} \mathrm{C} \mathrm{L}^{-1}\right)$ and above-average rates of sedimentation (5-30 $\mathrm{mg} \mathrm{cm}^{-2} \mathrm{~d}^{-1}$ ). Elevated concentrations of OM and increased rates of terrestrially derived sedimentation on coral reefs can cause a decline in hard coral cover and a relative increase in macroalgal cover, resulting in an overall degradation of coral reef habitat (Fabricius, 2005).

The amount of OM processed in coral reef sediments can be increased through several processes, two of which were simulated in this study: (1) through local phytoplankton blooms in the water column in response to the runoff of inorganic and organic nutrients and the eventual sediment deposition of dead phytoplankton, referred to herein as phytodetritus (Furnas et al., 2005), and (2) the release of coral mucus into the reef water column as a stress response of scleractinian corals to increased sedimentation and the subsequent sediment deposition of this bacteria-rich protein matrix (Ducklow and Mitchell, 1979). The sediment deposition of OM provides labile carbon substrate (and associated nitrogen and phosphorous) for immediate consumption by autotrophic and heterotrophic bacterial communities.

Studies which have examined the effect of increased concentrations of OM, such as coral mucus (e.g. Wild et al., 2004a; 24 h) or coral spawn and phytodetritus (e.g. Eyre et al., 2008; 1 week), on coral reef sediment metabolism have shown a short-term increase in GPP / $R$, contrasting the results provided from short-term temperature studies on coral reef sediments, where GPP / $R$ decreased (Trnovsky et al., 2016; $24 \mathrm{~h}$ ). Experimental additions of coral mucus from Acropora spp. on Heron Island, Australia (conducted only in the dark over $12 \mathrm{~h}$ ), induced a $\sim 1.5$-fold increase in $R$ (Wild et al., 2004b) while additions of Fungia spp. mucus from a reef in Aqaba, Jordan (also conducted over $12 \mathrm{~h}$ in the dark; Wild et al., 2005), showed a $\sim 1.9$-fold increase in $R$. OM associated with a mass coral spawning event (coral gametes and subsequent phytodetritus produced in the water column) on Heron Island, Australia, caused a 2.5 -fold increase in sediment $R$ and a 4-fold increase in sediment GPP over the course of 1 week (Glud et al., 2008). Unlike the short-term response in GPP / $R$ to $T$, sediment metabolism remained net-autotrophic during the spawning event at Heron Island, with GPP / $R$ ratios rising as high as 2.5-3.0 (Glud et al., 2008), implying that nutrients recycled from OM stimulated GPP in excess of $R$ (Eyre et al., 2008) on relatively short timescales (hours to days). However, studies which have examined the effect of excess OM on coral reef sediment metabolism over longer timescales (months) have shown that, ultimately, GPP / $R$ eventually shifts to net heterotrophy (e.g. Andersson, 2015; Yeakel et al., 2015; Muehllehner et al., 2016). This suggests that despite an initial OM-induced increase in GPP / $R$, the net long-term effect within reef sediments may be a preferentially heterotrophic recycling of nutrients released from organic matter degradation. Altogether, questions remain as to whether a predicted temperature-driven shift to net heterotrophy will be exacerbated or mitigated by the presence of excess organic matter filtered by coral reef sediments. There are, to date, no studies that have examined the effect of OM on coral reef sediment $G_{\text {net }}$. The observed short-term ( $24 \mathrm{~h}$ to 1 week) increase in GPP / $R$ in response to OM would imply that sediment $G_{\text {net }}$ may also increase given that coral reef sediments generally exhibit a positive GPP / $R-G_{\text {net }}$ relationship (Cyronak and Eyre, 2016), whereas the observed long-term (months) decrease in GPP / $R$ may also reduce sediment $G_{\text {net }}$. 
Therefore, seawater warming and $\mathrm{OM}$ enrichment will likely increase GPP and $R$ in coral reef sediments, but, altogether, there is a lack of research on how these perturbations, specifically in combination, will affect the balance in coral reef sediment organic (GPP/R) and inorganic $\left(G_{\text {net }}\right)$ metabolism. To meet these needs, this study performed incubations using benthic chambers placed in situ in a shallow coral reef sediment environment for a period of $24 \mathrm{~h}$. Phytodetritus and coral mucus were added to chamber seawater under ambient and increased SST $\left(+2.4{ }^{\circ} \mathrm{C}\right)$ conditions and the corresponding changes in GPP, $R$, and $G_{\text {net }}$ were measured. We hypothesised that the short-term combined treatments of seawater warming and OM loading would enhance GPP and $R$ in the sediment, but, given the previously shown short-term response in GPP / $R$ and $G_{\text {net }}$ to seawater warming (decrease in GPP / $R$ and $G_{\text {net }}$ ) and net response to OM enrichment (decrease in GPP / $R, G_{\text {net }}$ response unknown), there would be a net decrease in GPP / $R$ and $G_{\text {net }}$ relative to control treatments.

\section{Methods}

\subsection{Study site}

This study was conducted at Heron Island, Australia $\left(23^{\circ} 27^{\prime} \mathrm{S}, 151^{\circ} 55^{\prime} \mathrm{E}\right)$, in November 2016 . The island is situated near the Tropic of Capricorn, at the southern end of the Great Barrier Reef (GBR) and contains a $\sim 9$ ha island surrounded by a $\sim 24$ ha coral reef with an average hard coral cover of $\sim 39 \%$ (Salmond et al., 2015). The study site was located on the leeward side of the reef flat, roughly $100 \mathrm{~m}$ from the island shore, in a sandy patch where water depth varies between $\sim 0.1$ and $2.7 \mathrm{~m}$ due to semi-diurnal tidal changes. The site was predominately covered in permeable $\mathrm{CaCO}_{3}$ sediments $(\sim 63 \%)$ with interspersed patches of hard coral dominated by Acropora spp. (Roelfsema and Roelfsema, 2002). The $\mathrm{CaCO}_{3}$ sediment at this site has a $\sim 2: 1$ ratio of aragonite : high-magnesium calcite (Cyronak et al., 2013a). Sediment grain size at this site showed the following relative abundances at each listed size class (Cyronak et al., 2013b): $12.1 \%>2 \mathrm{~mm}, 30.5 \%$ between 1 and $2 \mathrm{~mm}$, $27.3 \%$ between $500 \mu \mathrm{m}$ and $1 \mathrm{~mm}, 14.1 \%$ between 250 and $500 \mu \mathrm{m}, 11.2 \%$ between 125 and $250 \mu \mathrm{m}, 4.2 \%$ between 63 and $125 \mu \mathrm{m}$, and $0.6 \%<63 \mu \mathrm{m}$. For a more detailed overview of the sediment grain characteristics at this site, we direct the reader to Glud et al. (2008) and Cyronak et al. (2013a, b).

\subsection{Experimental design}

A total of four $22 \mathrm{~h}$ diel incubations were conducted during 5-12 November 2016 in advective benthic chambers. Benthic net primary production (NPP), gross primary productivity (GPP), respiration $(R)$, and net calcification $\left(G_{\text {net }}\right)$ were compared under ambient $\left(\sim 0.63 \mu \mathrm{mol} \mathrm{CL}^{-1}\right)$ and elevated concentrations of particulate organic matter (OM; additions

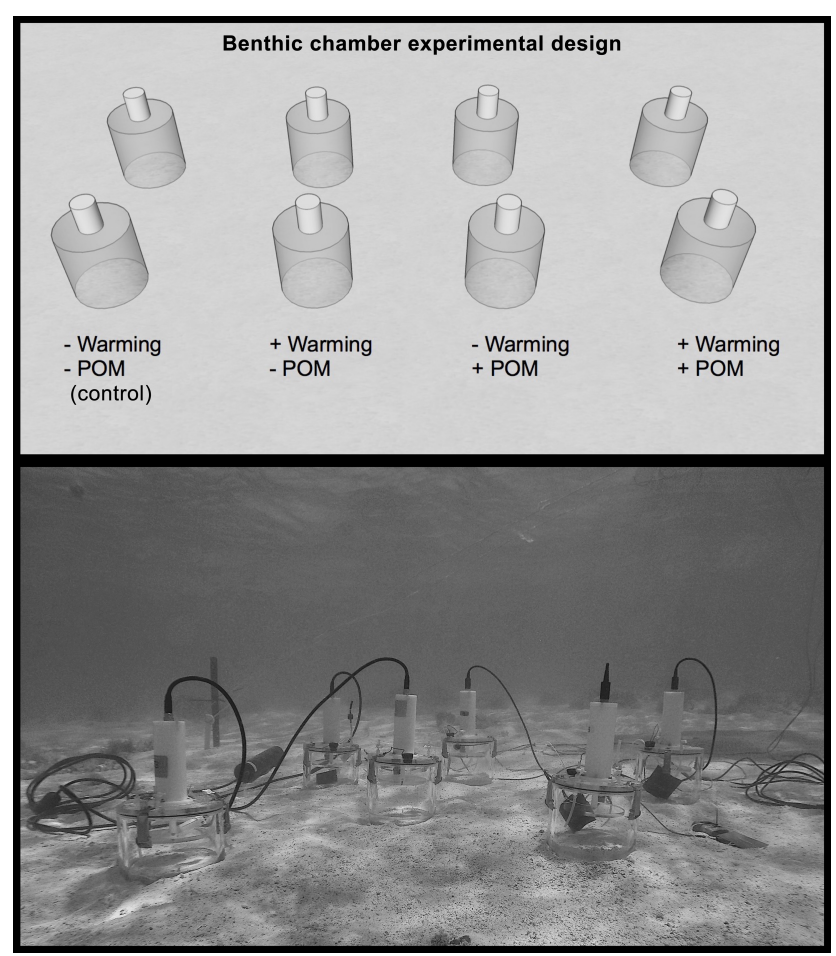

Figure 1. Layout of the experimental design using benthic chambers. Eight chambers were used in total, which provided two replicates per treatment. Chambers are organised by the presence $(+)$ and absence $(-)$ of the warming $\left(+2.4{ }^{\circ} \mathrm{C}\right)$ and organic matter $(\mathrm{OM}$; phytodetritus or coral mucus) treatments.

of $\sim 21.3 \mu \mathrm{mol} \mathrm{C} \mathrm{L}{ }^{-1}$ phytodetritus or $\sim 23.6 \mu \mathrm{mol} \mathrm{CL}^{-1}$ coral mucus) at $\sim 28.2$ and $\sim 30.6^{\circ} \mathrm{C}$ in an orthogonal design. Eight chambers were used per incubation day, with each of the four OM-temperature combinations replicated in two randomly assigned chambers (Fig. 1). The first two incubations included two replicate chambers using phytodetritus crossed with temperature (6 and 7 November 2016), while the next two incubations included two replicate chambers using coral mucus crossed with temperature (9 and 11 November 2016). Incubations were started at sunset (18:00) and ended the following day at dusk (16:00). This allowed for a $2 \mathrm{~h}$ period (16:00-18:00) where chambers could be moved to a new area of sediment, closed, and heated to the desired temperature offset before beginning the next set of incubations.

\subsection{Benthic chambers}

Advective benthic chambers were constructed out of clear acrylic with a height of $33 \mathrm{~cm}$ and a diameter of $19 \mathrm{~cm}$ (Huettel and Gust, 1992). A motorised clear disc in the top of the chamber was programmed to spin at a rate of 40 revolutions $\mathrm{min}^{-1}$, which had previously been determined to induce an advection rate of $\sim 43 \mathrm{~L} \mathrm{~m}^{-2} \mathrm{~d}^{-1}$ at the study site (Glud et al., 2008). About 10-12 cm of the base of the cham- 
Table 1. Concentrations of carbon $\left(\mu \mathrm{molCL} \mathrm{L}^{-1}\right)$ and nitrogen $\left(\mu \mathrm{mol} \mathrm{N} \mathrm{L}{ }^{-1}\right)$ and measured temperature $\left({ }^{\circ} \mathrm{C}\right)$ in the control and treatment chambers. Values correspond to the mean $\pm \mathrm{SD}$.

\begin{tabular}{lrrr}
\hline Treatment & $\begin{array}{r}\text { Carbon } \\
\left(\mu \mathrm{mol} \mathrm{C} \mathrm{L}{ }^{-1}\right)\end{array}$ & $\begin{array}{r}\text { Nitrogen } \\
\left(\mu \mathrm{mol} \mathrm{N}{ }^{-1}\right)\end{array}$ & $\begin{array}{r}\text { Temperature } \\
\left({ }^{\circ} \mathrm{C}\right)\end{array}$ \\
\hline$C$ & $0.63 \pm 0.13$ & $0.12 \pm 0.08$ & $28.2 \pm 1.1$ \\
$T$ & $0.63 \pm 0.13$ & $0.12 \pm 0.08$ & $30.6 \pm 1.0$ \\
$\mathrm{PD}$ & $21.7 \pm 1.0$ & $2.3 \pm 0.8$ & $28.4 \pm 1.0$ \\
$T+\mathrm{PD}$ & $21.7 \pm 1.0$ & $2.3 \pm 0.8$ & $30.5 \pm 0.9$ \\
$\mathrm{CM}$ & $24.2 \pm 1.1$ & $1.5 \pm 0.4$ & $28.3 \pm 0.8$ \\
$T+\mathrm{CM}$ & $24.2 \pm 1.1$ & $1.5 \pm 0.4$ & $30.7 \pm 1.1$ \\
\hline
\end{tabular}

ber was inserted into the sediment such that a $\sim 4 \mathrm{~L}$ water column of seawater was enclosed within the chamber (height $\sim 15 \mathrm{~cm}$ ) upon closing of the lid. The exact water volume varied within each chamber and was calculated for each incubation by multiplying known areal coverage by measured chamber height (at three positions above the sediment). Prior to closing the chambers, the tops were left open for $\sim 1 \mathrm{~h}$ to allow settlement of disturbed sediment. Chambers were then sealed $\sim 1 \mathrm{~h}$ prior to the beginning of each incubation to allow each temperature treatment chamber to reach the desired temperature offset. Following this, at the beginning of each incubation, selected chambers (four of the eight) were injected with OM (either coral mucus or phytodetritus).

\subsection{Temperature manipulation}

The international panel on climate change (IPCC) representative concentration pathway (RCP) 8.5 projects an average 2.2-2. $7^{\circ} \mathrm{C}$ increase in SST (IPCC, 2013). A similar increase in temperature within the benthic chambers was achieved with $5 \mathrm{~W}$ silicone heating pads (RS Australia) inserted inside of each of the four temperature treatment chambers (e.g. Trnovsky et al., 2016). These pads resided in the middle of the chamber water column and were powered by a $12 \mathrm{~V}$ battery on a surface support station tethered roughly $3 \mathrm{~m}$ away. Temperature and light was measured in all eight chambers and in the water column using HOBO temperature loggers, which recorded temperature $\left({ }^{\circ} \mathrm{C}\right)$ and light (lux) at an interval of $15 \mathrm{~min}$. Light intensity (lux) was converted to $\mu \mathrm{mol}$ quanta of photosynthetic active radiation (PAR) $\mathrm{m}^{-2} \mathrm{~s}^{-1}$ using a conversion factor of 0.0185 , derived from correlations with PAR measurements of a calibrated ECO-PAR (Wetlabs) sensor over a period of 5 days $\left(R^{2}=0.89\right)$.

Heating pads increased temperature $(T)$ within the chambers by $2.4 \pm 0.5^{\circ} \mathrm{C}$ and maintained this offset on top of the natural diel temperature fluctuations measured in the control chambers (Table 1). As HOBO temperature loggers may record potentially seawater temperatures higher than the surroundings due to internal heating of the transparent plastic casing (Bahr et al., 2016; Trnovsky et al., 2016), HOBO temperature data was corrected for precision ( $48 \mathrm{~h}$ side-by-side logging of all nine loggers in an aquarium) and accuracy (deployment next to an in situ SeapHOx (Sea-Bird Electronics) for $48 \mathrm{~h}$ ). The conductivity sensor of the SeapHOx was used to record water column salinity for the duration of the experiment ( 7 days) at a sampling frequency of $30 \mathrm{~min}$.

\subsection{Organic matter manipulations}

Phytodetritus (PD) was injected into treatment chambers to achieve a concentration increase by $\sim 20 \mu \mathrm{mol} \mathrm{C} \mathrm{L}^{-1}$, a value analogous to mean conditions observed on degraded eutrophic coral reefs, where water column concentrations can range from 10 to $50 \mu \mathrm{mol} \mathrm{C} \mathrm{L}^{-1}$ (Fabricius, 2005; DiazOrtega and Hernandez-Delgado, 2014). Phytodetritus was produced from unfiltered seawater $(6 \mathrm{~L})$ collected from the coastal ocean adjacent to the SCU laboratories (Lennox Head, NSW, Australia) and containing naturally occurring assemblages of phytoplankton species common to the East Australian current. Phytoplankton growth in the collected seawater was stimulated by additions of $128 \mu \mathrm{mol} \mathrm{L}^{-1} \mathrm{NO}_{3}^{-}$, $8 \mu \mathrm{mol} \mathrm{L}{ }^{-1} \mathrm{PO}_{4}^{3-}$, and $128 \mu \mathrm{mol} \mathrm{L}^{-1} \mathrm{H}_{4} \mathrm{SiO}_{4}$ (buffered by additions of $256 \mu \mathrm{mol} \mathrm{L} \mathrm{L}^{-1}$ of $\mathrm{HCl}$ ), and a solution of trace metals and vitamins $\left(F_{1 / 8} ;\right.$ Guillard, 1975). Total amounts of nutrients were chosen to allow for a community production of up to $850 \mu \mathrm{mol} \mathrm{C} \mathrm{L}{ }^{-1}$ assuming a classical $\mathrm{C}: \mathrm{N}: \mathrm{P}$ Redfield ratio of $116: 16: 1$ and a $\mathrm{N}: \mathrm{Si}$ requirement of diatoms of 1 . After 1 week of incubation at $150 \mu \mathrm{mol}$ quanta of PAR $\mathrm{m}^{-2} \mathrm{~s}^{-1}$ at $20^{\circ} \mathrm{C}$, the phytoplankton community was concentrated to $1 / 50$ th the original volume $(0.12 \mathrm{~L})$ via gentle ( $>-0.2$ bar) vacuum filtration over $\mathrm{GF} / \mathrm{F}$ filters and rinsed with artificial seawater to remove residual concentrations of dissolved organic and inorganic nutrients. The resulting phytoplankton concentrate (measured at $8.5 \mathrm{mmol} \mathrm{C} \mathrm{mL}^{-1}$ and $0.9 \mathrm{mmol} \mathrm{N} \mathrm{mL}^{-1}$ of particulate organic carbon (POC) and nitrogen (PON) respectively per $1 \mathrm{~mL}$ of PD concentrate; see Sect. 2.6 for details) was stored in the dark at $4.0^{\circ} \mathrm{C}$ until experimental use ( 6 days). At the beginning of an incubation, $10 \mathrm{~mL}$ of the dead phytoplankton concentrate, referred to as PD hereafter, was injected into each treatment chamber $(\sim 4 \mathrm{~L}$ volume), raising the concentration of carbon and nitrogen by $\sim 21.3 \pm 1.0 \mu \mathrm{mol} \mathrm{C} \mathrm{L}^{-1}$ and $\sim 2.2 \pm 0.8 \mu \mathrm{mol} \mathrm{N} \mathrm{L}{ }^{-1}$ respectively (Table 1 ).

The amount of coral mucus (CM) added to the chambers was chosen to represent a reef-wide discharge based on reported average mucus secretion rates for Acropora

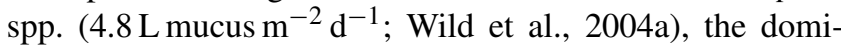
nant genus on the Heron Island reef flat. Mucus was collected from scattered branching coral fragments (Acropora spp.) using a non-destructive method whereby loose individual colonies naturally exposed to air during low tide were inverted so that gravity facilitated the pooling of secreted mucus through a cone filter into a $5 \mathrm{~L}$ beaker. This mucus was returned to the lab, particle filtered $(5.0 \mu \mathrm{M})$ to remove the bulk of seawater, re-filtered to separate out particle carbonates, and stored in the dark at $4.0^{\circ} \mathrm{C}$ until experimental use 
(2 days). vNinety-four millilitres of mucus was injected into each treatment chamber to simulate the equivalent reported

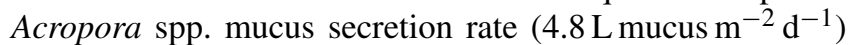
for Heron Island given the average percent of this secreted mucus filtered by the sand $(\sim 70 \%$; Wild et al., 2004a) and the benthic area enclosed by each chamber $\left(0.028 \mathrm{~m}^{2}\right)$. Based on measured POC and PON concentrations of the mucus $\left(1.2 . \mathrm{mmol} \mathrm{C} \mathrm{mL}^{-1}\right.$ and $0.08 \mathrm{mmol} \mathrm{N} \mathrm{mL}^{-1}$ respectively per $12 \mathrm{~mL}$ of $\mathrm{CM}$ concentrate; see Sect. 2.6) this represented an addition of $\sim 23.6 \pm 1.1 \mu \mathrm{mol} \mathrm{CL}^{-1}$ and $1.4 \pm 0.4 \mu \mathrm{mol} \mathrm{N} \mathrm{L}^{-1}$ (Table 1).

\subsection{Sample collection and analysis}

Seawater samples $(120 \mathrm{~mL}$ total) were extracted from the top of each chamber via two two-port valves using two $60 \mathrm{~mL}$ syringes without headspace at $\sim 12 \mathrm{~h}$ intervals (sunset, dawn, and dusk) and returned to the lab for immediate analysis and/or preservation. $10 \mathrm{~mL}$ of unfiltered seawater from each chamber was analysed for dissolved oxygen (DO; $\mathrm{mg} \mathrm{L}^{-1}$ ) with a Hach HQ30D meter and Luminescent DO (LDO) probe. Samples for seawater total alkalinity $\left(A_{\mathrm{T}} ; \mu \mathrm{mol} \mathrm{kg}{ }^{-1}\right)$ were filtered $(0.45 \mu \mathrm{m}$; Chanson and Millero, 2007) and stored in $100 \mathrm{~mL}$ plastic, airtight bottles for immediate analysis $(<24 \mathrm{~h})$. Samples for dissolved inorganic carbon (DIC; $\left.\mu \mathrm{mol} \mathrm{kg}^{-1}\right)$ were also filtered $(0.45 \mu \mathrm{M})$ into the bottom of $6 \mathrm{~mL}$ vials with $5 \mathrm{~mL}$ overflow, poisoned ( $6 \mu \mathrm{L}$ of saturated $\mathrm{HgCl}_{2}$; Dickson et al., 2007) and crimped (rubber butyl septum).

Seawater $A_{\mathrm{T}}$ was analysed using a potentiometric titration method (Dickson et al., 2007) on a Metrohm 888 Titrando automatic titrator using $\sim 10 \mathrm{~mL}$ of weighed-in seawater per sample. DIC was analysed in triplicates on a Marianda AIRICA coupled to a LI-COR LI $7000 \mathrm{CO}_{2} / \mathrm{H}_{2} \mathrm{O}$ analyser on $0.4 \mathrm{~mL}$ of seawater per sample. $A_{\mathrm{T}}$ and DIC sample precision was estimated with replicate analyses conducted on every fifth sample $\left(A_{\mathrm{T}} \mathrm{SD}= \pm 1.7 \mu \mathrm{mol} \mathrm{kg}{ }^{-1}\right.$; DIC $\mathrm{SD}=$ $\left.\pm 1.8 \mu \mathrm{mol} \mathrm{kg}^{-1}\right)$. Measurements were corrected against certified reference material (CRM; Batch 155) from the Scripps Institute of Oceanography ( $A_{\mathrm{T}} \mathrm{SD}= \pm 2.2 \mu \mathrm{mol} \mathrm{kg}{ }^{-1}$; DIC $\left.\mathrm{SD}= \pm 1.3 \mu \mathrm{mol} \mathrm{kg}{ }^{-1}\right)$. Parameters for the seawater carbonate system $\left(\Omega_{\mathrm{ar}} ; \mathrm{pH}_{\mathrm{T}}\right.$, total scale) were calculated from measured $A_{\mathrm{T}}$, DIC, temperature, and salinity using the $\mathrm{R}$ package seacarb (Lavigne and Gattuso, 2013) with $K_{1}$ and $K_{2}$ constants applied from Mehrbach et al. (1973) and refit by Dickson and Millero (1987) and the total borate-to-salinity relationship adapted from Lee and Millero (1995). Because changes in $A_{\mathrm{T}}$ could be due to processes other than the precipitation and dissolution of carbonates (e.g. sulfate reduction associated with organic matter additions), fluxes in DIC were corrected for the assumed $A_{\mathrm{T}}$ fluxes due to calcium carbonate precipitation/dissolution $\left(0.5 \mathrm{~mol} \mathrm{CO}_{2}: 1 \mathrm{~mol} A_{\mathrm{T}}\right)$ and compared against fluxes in $\mathrm{O}_{2}$, with an expected $1: 1$ molar flux ratio $\left(\mathrm{DIC}_{\mathrm{org}}: \mathrm{O}_{2}\right)$.
Prior to chamber additions, subsamples $(1 \mathrm{~mL}, n=3)$ were taken from the concentrated PD culture, CM, and the water column and analysed for particulate organic carbon (POC) and nitrogen (PON). These subsamples were filtered on pre-combusted $25 \mathrm{~mm} \mathrm{GF} / \mathrm{F}$ filters, dried at $60^{\circ} \mathrm{C}$, fumed with $12 \mathrm{M} \mathrm{HCl}$ to dissolve any particulate carbonates on the filter, and wrapped in pre-combusted tin capsules. These capsules were analysed for carbon (C) and nitrogen (N) using an elemental analyser (Thermo Flash ES) coupled to an isotope ratio mass spectrometer (Thermo Delta V PLUS) via a Thermo Conflo V (see Eyre et al., 2016, for details).

\subsection{Calculating sediment metabolism}

Benthic metabolism (NPP, GPP, $R, G_{\text {net }}$ ) in each chamber was estimated based on the fluxes of measured solutes (DO, and $A_{\mathrm{T}}$ respectively). For flux calculations, DO was converted from $\mathrm{mg} \mathrm{L}^{-1}$ to $\mathrm{mmol} \mathrm{L}^{-1}$. $A_{\mathrm{T}}$ and DIC were converted from $\mu \mathrm{mol} \mathrm{kg}{ }^{-1}$ to $\mathrm{mmol} \mathrm{L}^{-1}$ using calculated temperature- and salinity-dependent seawater density. The solute flux equation (Glud et al., 2008) was as follows:

$F=\frac{\Delta S \times v}{A \times \Delta t}$,

where $F\left(\mathrm{mmol} \mathrm{m}^{-2} \mathrm{~h}^{-1}\right)$ is the net flux in solute, $\Delta S$ $\left(\mathrm{mmol} \mathrm{L}^{-1}\right)$ is the change in solute concentration, $v(\mathrm{~L})$ is the chamber volume, $A\left(\mathrm{~m}^{2}\right)$ is the area of sediment enclosed by the chamber, and $\Delta t$ (hours) is the time elapsed between seawater samplings. Rates of sediment net primary production (NPP), gross primary production (GPP), and respiration $(R)$ were calculated from $\mathrm{O}_{2}$ fluxes $\left(\mathrm{mmol} \mathrm{O}_{2} \mathrm{~m}^{-2} \mathrm{~h}^{-1}\right)$, and rates of net sediment calcification $\left(G_{\text {net }}\right)$ were calculated from $A_{\mathrm{T}}$ fluxes $\left(\mathrm{mmol} \mathrm{CaCO}_{3} \mathrm{~m}^{-2} \mathrm{~h}^{-1}\right.$; Table 2). Both NPP and GPP are reported as positive values to represent flux of $\mathrm{O}_{2}$ from the sediment into the chamber water column, whereas $R$ is reported as a negative value to represent the flux of $\mathrm{O}_{2}$ from chamber water column into the sediment. To calculate the GPP / $R$ ratio, positive values of $R$ were used. To determine the sensitivity of GPP and $R$ to changes in temperature, the absolute difference in diel GPP and $R\left(\mathrm{mmol} \mathrm{O}_{2} \mathrm{~m}^{-2} \mathrm{~d}^{-1}\right)$ between the control and warming treatments was divided by the increase in temperature $\left(2.4 \pm 0.5^{\circ} \mathrm{C}\right)$ to provide a $\mathrm{mmol} \mathrm{O}_{2} \mathrm{~m}^{-2} \mathrm{~d}^{-1}{ }^{\circ} \mathrm{C}^{-1}$ sensitivity metric. Additionally, to provide comparability with the literature and determine the numerical relationship between a $10^{\circ} \mathrm{C}$ change in temperature and GPP and $R, Q_{10}$ values were estimated for temperature treatments according to the following equation:

$Q_{10}=\left(\frac{M 2}{M 1}\right)^{\left(\frac{10}{T_{2}-T_{1}}\right)}$,

where $M 1$ is the metabolic rate (GPP or $R$ ) at temperature $T_{1}$ (control) and $M 2$ is the metabolic rate (GPP or $R$ respectively) at temperature $T_{2}$ (warming treatment), with $T_{1}<T_{2}$. 
Table 2. The equations used in this study to calculate rates of sediment metabolism based on measured fluxes in dissolved oxygen (DO) and total alkalinity $\left(A_{\mathrm{T}}\right.$; Eyre et al., 2011).

\begin{tabular}{ll}
\hline Metabolic rate & Definition \\
\hline $\begin{array}{l}\text { Respiration }(R) \\
\text { Net primary production }\end{array}$ & $\begin{array}{l}\text { Dark DO flux } \times-1 \\
\text { Light DO flux }\end{array}$ \\
$\begin{array}{l}\text { Gross primary production } \\
(\mathrm{GPP})\end{array}$ & $\mathrm{NPP}+R$ \\
GPP $/ R$ & $\mathrm{GPP} \times 12$ (daylight hours $) / R \times 24$ \\
& $($ total hours $)$ \\
Net calcification $\left(G_{\text {net }}\right)$ & $\begin{array}{l}A_{\mathrm{T}} \text { flux } \times 0.5 ; \text { positive values } \\
\text { represent net calcification and } \\
\end{array}$ \\
& $\begin{array}{l}\text { negative rates represent } \\
\text { net dissolution }\end{array}$ \\
\hline
\end{tabular}

\subsection{Statistical analyses}

Results are displayed as the mean \pm standard deviation (SD). Data were organised as the hourly average for both day and night and were pooled together within each $T$, OM, and $T+$ OM treatment where results did not significantly differ between incubations. All statistical analyses were performed with the SPSS statistics software (SPSS Inc. Version 22.0) running in a Windows PC environment, and the assumptions of normality and equality of variance were evaluated with graphical analyses of the residuals. To test for the effect of each treatment ( $T$, PD, and $\mathrm{CM}$ ) on respiration, photosynthesis, and calcification, measured $R$, NPP, GPP, and $G_{\text {net }}$ were analysed using a repeated-measures three-way analysis of variance (ANOVA). In this model, temperature and OM (PD and $\mathrm{CM}$ ) were fixed effects, the within-subject factor was time (days), and replicate chambers were a nested effect. To compare the significance of temperature and OM between and within treatment chambers, a one-way ANOVA model was used in which average seawater temperatures $\left({ }^{\circ} \mathrm{C}\right)$ and POC and PON concentrations respectively were treated as the response variable. In these analyses, Bonferroni post hoc tests were used to conduct pair-wise comparisons between treatments.

\section{Results}

\subsection{Measured seawater chemistry and sediment metabolism in control chambers}

Temperatures measured in both the water column and chambers exhibited typical diel changes, and were slightly warmer in the controls $\left(28.2 \pm 1.3^{\circ} \mathrm{C}\right)$ in comparison to the water column $\left(-0.8 \pm 0.5^{\circ} \mathrm{C}\right.$; Fig. 2). Mean water column salinity throughout the experiment was $35.8 \pm 0.1$. Over the course of each diel incubation period, changes in water chemistry (Fig. 3) were driven by benthic metabolism.
Control $(C)$ chambers, over the diel cycle, were net autotrophic and net calcifying. $C$ chambers were net dissolving at night and net calcifying during the day. Mean particulate organic carbon (POC) and nitrogen (PON) concentrations in the four $C$ chambers were $0.63 \pm 0.1 \mu \mathrm{mol} \mathrm{CL}^{-1}$ and $0.12 \pm 0.1 \mu \mathrm{mol} \mathrm{N} \mathrm{L}{ }^{-1}$ respectively. The $\mathrm{DIC}_{\text {org }}: \mathrm{O}_{2}$ quotient for all treatments was $0.94 \pm 0.09$ on average and did not significantly differ from 1 ( $p<0.05$; Fig. 4 ), suggesting that sulfate reduction did not significantly contribute to the $A_{\mathrm{T}}$ fluxes.

\subsection{The effects of temperature on sediment metabolism}

Mean seawater temperature in the $C$ and temperature $(T)$ treatments during the four incubation periods was $28.2 \pm 1.1$ and $30.6 \pm 1.2^{\circ} \mathrm{C}$ respectively (Table 1 ). Temperature differed between $C$ and $T$ treatments $\left(F_{1,31}=384.38\right.$, $p<0.05$ ), but there was no significant difference between replicate chambers within each treatment $\left(F_{1,31}=0.76\right.$, $p=0.768$ ). Temperature in all eight chambers exhibited typical diel changes throughout all four incubation periods, driven by sunlight and tidal changes in water depth (Fig. 2). Treatment chambers followed the same natural diel change measured in control chambers and maintained an average $+2.4 \pm 0.5^{\circ} \mathrm{C}$ offset over the course of the study (Table 1 ).

During the fourth set of incubations, one $T$ treatment was lost due to a broken heater and this chamber was treated as a third control. Seawater warming increased $R\left(F_{1,31}=260.38, p<0.05\right)$, NPP $\left(F_{1,31}=192.17\right.$, $p<0.05)$, and GPP $\left(F_{1,31}=160.61, p<0.05\right.$; Table 3, Fig. 5). Overall, warming decreased GPP $/ R\left(F_{1,31}=79.02\right.$, $p<0.05)$ from a state of net autotrophy to net heterotrophy (Fig. 6). Mean calculated temperature sensitivity, averaged across $T$ treatments from all four incubations, was $22.3 \pm 3.8 \mathrm{mmol} \mathrm{O}_{2} \mathrm{~m}^{-2} \mathrm{~d}^{-1}{ }^{\circ} \mathrm{C}^{-1}$ for $R$ and $16.1 \pm 2.8 \mathrm{mmol} \mathrm{O}_{2} \mathrm{~m}^{-2} \mathrm{~d}^{-1}{ }^{\circ} \mathrm{C}^{-1}$ for GPP. Mean calculated $\mathrm{Q}_{10}$ values were $10.7 \pm 3.1$ for $R$ and $7.3 \pm 1.2$ for GPP. Warmed chambers were net dissolving at night and net calcifying during the day. Overall, warming caused a net decrease in diel $G_{\text {net }}\left(F_{1,31}=122.82, p<0.05\right)$ from a state of net calcification to net dissolution (Fig. 7).

\subsection{The effects of organic matter on sediment metabolism}

Mean POC and PON concentrations in the four phytodetritus (PD) treatment chambers were $21.7 \pm 1.0 \mu \mathrm{mol} \mathrm{CL^{-1 }}$ and $2.3 \pm 0.8 \mu \mathrm{mol} \mathrm{NL} L^{-1}$ respectively (POC: $\mathrm{PON} \sim 9$ : 1 ; Table 1). PD increased $R\left(F_{1,15}=16.77, p<0.05\right)$, NPP $\left(F_{1,15}=245.86, p<0.05\right)$, and GPP $\left(F_{1,15}=212.64\right.$, $p<0.05)$. Overall, PD caused a net increase in GPP $/ R$ $\left(F_{1,15}=13.92, p<0.05\right.$; Table 3$)$. Chambers treated with PD were net dissolving at night and net calcifying during the day. Overall, PD caused a net increase in diel $G_{\text {net }}$ $\left(F_{1,15}=134.27, p<0.001\right)$. 
Table 3. Calculated respiration $\left(R: \mathrm{mmol} \mathrm{O}_{2} \mathrm{~m}^{-2} \mathrm{~h}^{-1}\right)$, net primary productivity (NPP: $\mathrm{mmol}_{2} \mathrm{~m}^{-2} \mathrm{~h}^{-1}$ ), gross primary productivity (GPP: $\left.\mathrm{mmol} \mathrm{O}_{2} \mathrm{~m}^{-2} \mathrm{~h}^{-1}\right)$, the ratio of GPP / $R$, and net calcification $\left(G_{\text {net }}: \mathrm{mmol} \mathrm{CaCO}_{3} \mathrm{~m}^{-2} \mathrm{~h}^{-1}\right)$ in the control and treatment chambers. Values correspond to the mean $\pm \mathrm{SD}$.

\begin{tabular}{|c|c|c|c|c|c|c|c|}
\hline Treatment & $\begin{array}{r}R \\
\left(\mathrm{mmol} \mathrm{O}_{2} \mathrm{~m}^{-2} \mathrm{~h}^{-1}\right)\end{array}$ & $\begin{array}{r}\mathrm{NPP} \\
\left(\mathrm{mmol} \mathrm{O}_{2} \mathrm{~m}^{-2} \mathrm{~h}^{-1}\right)\end{array}$ & $\begin{array}{r}\text { GPP } \\
\left(\mathrm{mmol} \mathrm{O}_{2} \mathrm{~m}^{-2} \mathrm{~h}^{-1}\right)\end{array}$ & GPP / $R$ & $\begin{array}{r}\text { Day } G_{\text {net }} \\
\left(\mathrm{mmol} \mathrm{CaCO}_{3} \mathrm{~m}^{-2} \mathrm{~h}^{-1}\right)\end{array}$ & $\begin{array}{r}\text { Night } G_{\text {net }} \\
\left(\mathrm{mmol} \mathrm{CaCO}_{3} \mathrm{~m}^{-2} \mathrm{~h}^{-1}\right)\end{array}$ & $\begin{array}{r}\text { Diel } G_{\text {net }} \\
\left(\mathrm{mmol} \mathrm{CaCO}_{3} \mathrm{~m}^{-2} \mathrm{~h}^{-1}\right)\end{array}$ \\
\hline$C$ & $-1.3 \pm 0.5$ & $1.9 \pm 0.3$ & $3.2 \pm 0.4$ & $1.31 \pm 0.1$ & $1.3 \pm 0.2$ & $-0.9 \pm 0.2$ & $0.2 \pm 0.2$ \\
\hline$T$ & $-3.5 \pm 0.4$ & $2.9 \pm 0.4$ & $6.4 \pm 0.5$ & $0.91 \pm 0.1$ & $1.7 \pm 0.2$ & $-1.9 \pm 0.2$ & $-0.2 \pm 0.1$ \\
\hline PD & $-2.6 \pm 0.5$ & $5.3 \pm 0.5$ & $7.9 \pm 0.4$ & $1.54 \pm 0.1$ & $2.8 \pm 0.3$ & $-1.5 \pm 0.2$ & $0.6 \pm 0.2$ \\
\hline$T+\mathrm{PD}$ & $-3.1 \pm 0.5$ & $4.7 \pm 0.5$ & $7.8 \pm 0.5$ & $1.27 \pm 0.1$ & $2.6 \pm 0.3$ & $-1.9 \pm 0.2$ & $0.3 \pm 0.1$ \\
\hline $\mathrm{CM}$ & $-2.0 \pm 0.4$ & $4.4 \pm 0.4$ & $6.4 \pm 0.7$ & $1.61 \pm 0.2$ & $2.4 \pm 0.3$ & $-1.3 \pm 0.2$ & $0.5 \pm 0.2$ \\
\hline$T+\mathrm{CM}$ & $-2.9 \pm 0.4$ & $4.6 \pm 0.5$ & $7.4 \pm 0.5$ & $1.25 \pm 0.1$ & $2.3 \pm 0.4$ & $-1.8 \pm 0.3$ & $0.2 \pm 0.2$ \\
\hline
\end{tabular}
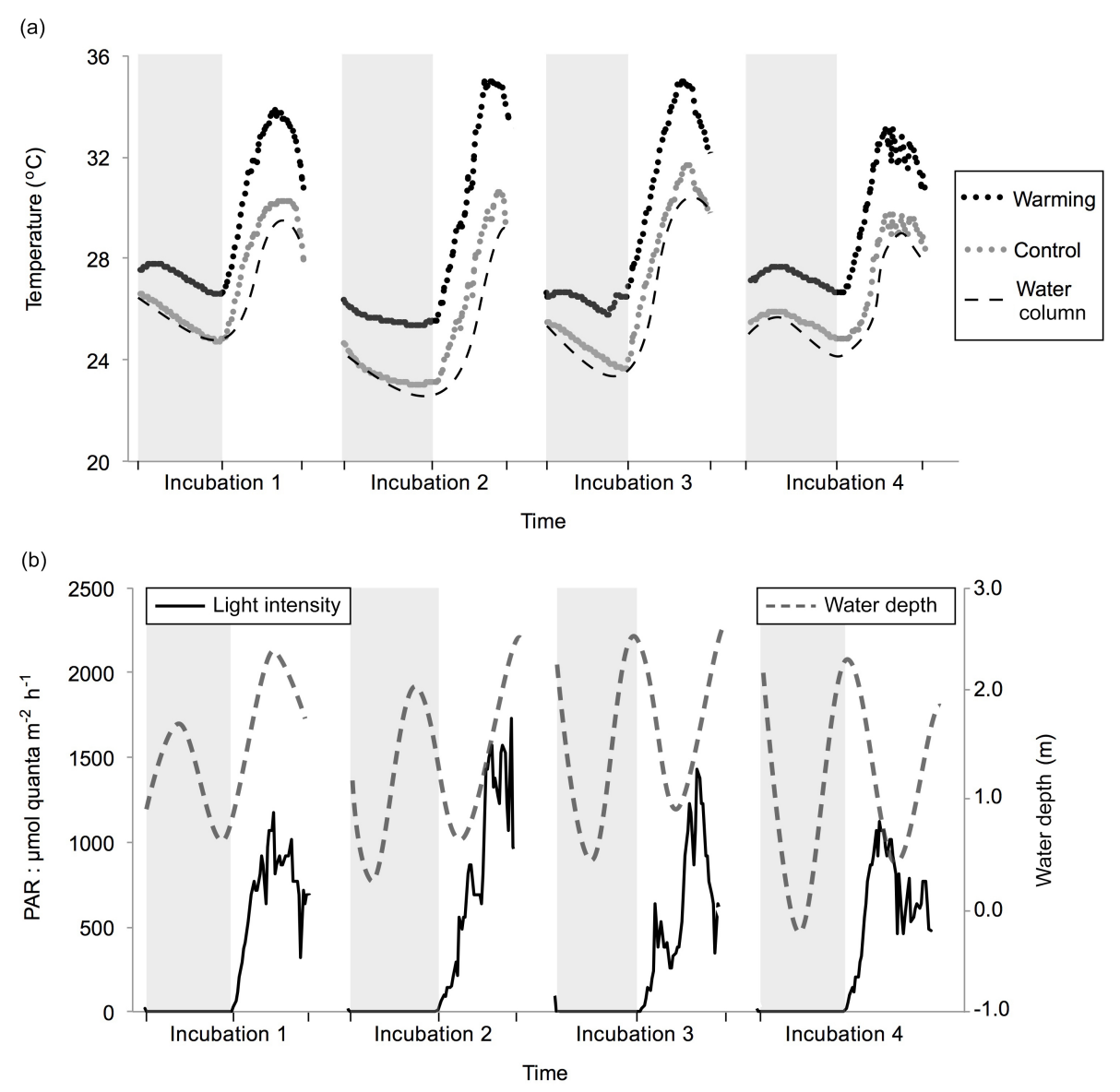

Figure 2. Water column parameters measured during the four incubations, each starting at sunset (18:00) and ending at the following day's dusk (16:00). Data are presented from the first phase (Incubation 1 and 2) where phytodetritus was used as an organic matter (OM) treatment, and from the second phase (Incubation 3 and 4), where coral mucus was used as an OM treatment. Shaded grey bars represent night-time. (a) Mean temperature $\left({ }^{\circ} \mathrm{C}\right)$ measured by Hobo temperature recorders that logged temperature at 15 min intervals during each incubation period. Data are pooled together as the mean from control (grey dots) and warming (black dotted line) treatments $(n=4$ per incubation). Mean water column temperature ( $n=1$ per incubation) shown as a black dashed line. (b) Measured light intensity ( $\mu$ mol quanta $\mathrm{m}^{-2} \mathrm{~s}^{-1}$ ) in the water column (black line) and water height $(\mathrm{m})$ during each incubation period (grey dashed line).

Mean POC and PON concentrations in the four coral mucus $(\mathrm{CM})$ treatment chambers were $24.2 \pm 1.1 \mu \mathrm{mol} \mathrm{C} \mathrm{L}{ }^{-1}$ and $1.5 \pm 0.4 \mu \mathrm{mol} \mathrm{N} \mathrm{L}{ }^{-1}$ respectively (POC:PON ratio $\sim 16: 1)$. CM increased $R\left(F_{1,15}=7.34, p<0.05\right)$, NPP $\left(F_{1,15}=134.51, p<0.05\right)$, and GPP $\left(F_{1,15}=99.24\right.$, $p<0.05)$. Overall, CM caused a net increase in GPP $/ R$
$\left(F_{1,15}=34.17, p<0.05\right.$; Table 3$)$. Chambers treated with $\mathrm{CM}$ were net dissolving at night and net calcifying during the day. Overall, CM caused a net increase in diel $G_{\text {net }}\left(F_{2,22}=\right.$ 100.61, $p<0.05)$. 

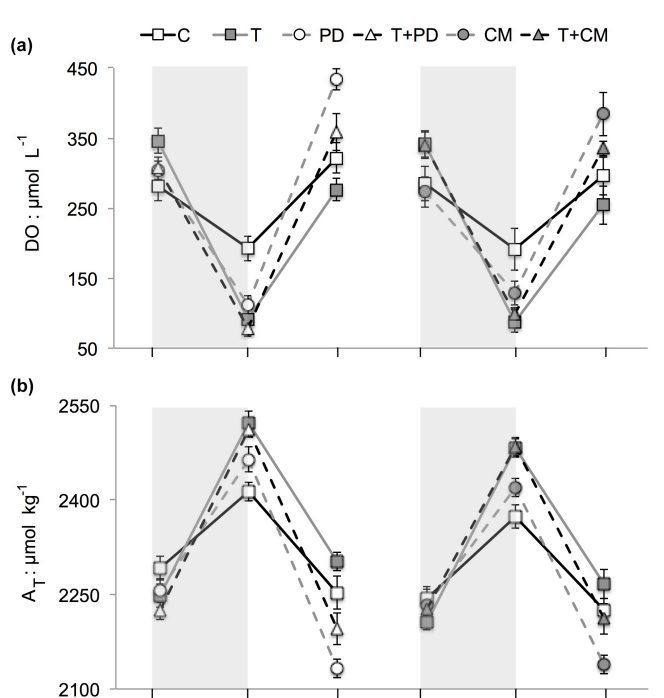

(c)

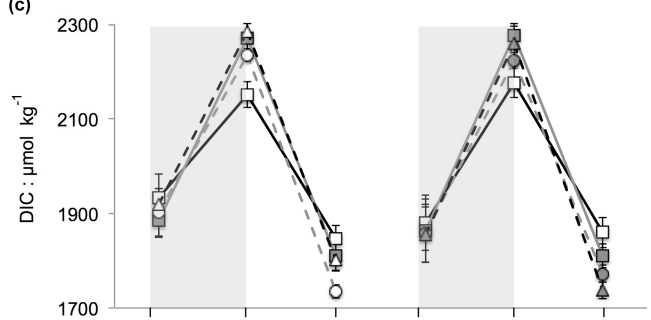

(d)
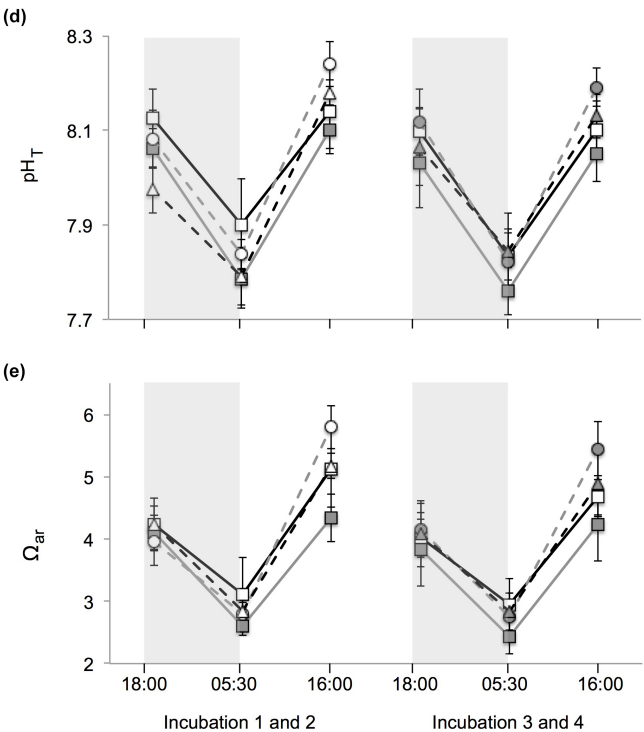

Figure 3. Water chemistry (mean $\pm \mathrm{SD}$ ) measured and calculated during the four incubations. Control $(C)$, warming $(T)$, phytodetritus (PD), coral mucus (CM), and combination $(T+\mathrm{PD}, T+\mathrm{CM})$ treatments are averaged over the two incubations (and replicate chambers therein) in which each respective OM treatment was used $(n=4)$. Shaded grey bars represent the dark, and time of sampling is labelled on the $x$ axis. (a) Measured fluxes in dissolved oxygen (DO: $\mu \mathrm{mol} \mathrm{\textrm {L } ^ { - 1 }}$ ). (b) Measured fluxes in total alkalinity $\left(A_{\mathrm{T}}: \mu \mathrm{mol} \mathrm{kg}{ }^{-1}\right)$. (c) Measured fluxes in dissolved inorganic carbon (DIC: $\mu \mathrm{mol} \mathrm{kg} \mathrm{kg}^{-1}$ ). (d) Calculated changes in $\mathrm{pH}$ (total scale: $\left.\mathrm{pH}_{\mathrm{T}}\right)$. (e) Calculated fluxes in aragonite saturation state $\left(\Omega_{\mathrm{ar}}\right)$.

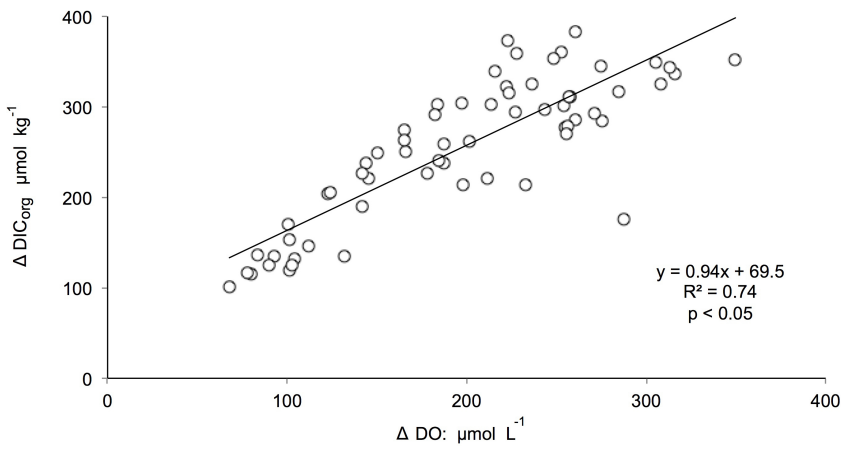

Figure 4. A linear correlation between calculated changes in dissolved inorganic carbon $\left(\triangle \mathrm{DIC}\right.$ org $\left.: \mu m o \mathrm{~kg}^{-1}\right)$ as a function of measured changes in dissolved oxygen $\left(\Delta \mathrm{DO}: \mu \mathrm{mol} \mathrm{L}{ }^{-1}\right)$ over each $12 \mathrm{~h}$ sampling period from all chambers and incubations. To examine the variation in DIC due solely to photosynthesis and respiration (DIC $\mathrm{Drg}_{\text {org }}$, changes in DIC were corrected for calcium carbonate precipitation/dissolution using the measured changes in total alkalinity $\left(A_{\mathrm{T}} ; 0.5 \mathrm{~mol} \mathrm{CO} 2: 1 \mathrm{~mol} A_{\mathrm{T}}\right)$.

\subsection{The combined effects of temperature and organic matter on sediment metabolism}

In the first two incubations, $T+\mathrm{PD}$ increased $R$ $\left(F_{1,15}=46.4 p<0.001\right), \quad \mathrm{NPP}\left(F_{1,15}=16.31, p<0.05\right)$, and GPP $\left(F_{1,15}=8.81, p<0.05\right.$; Table 3$)$. However, GPP $/ R$ in $T+$ PD treatments did not significantly differ from control chambers $\left(F_{1,15}=2.75, p=0.122\right)$. Chambers treated with $T+\mathrm{PD}$ were net dissolving at night and net calcifying during the day. Overall, diel $G_{\text {net }}$ in $T+\mathrm{PD}$ treatments did not significantly differ from control chambers $\left(F_{1,15}=0.70, p=0.417\right)$.

In the two last incubations $T+\mathrm{CM}$ increased $R$ $\left(F_{1,15}=7.75, p<0.05\right), \operatorname{NPP}\left(F_{1,15}=17.19, p<0.05\right)$, and GPP $\left(F_{1,15}=26.77, p<0.05\right.$; Table 3$)$. With a value of $1.21 \pm 0.13$, GPP $/ R$ in the $T+\mathrm{CM}$ treatments was again not significantly different from control chambers $\left(F_{1,15}=3.79, p=0.075\right) . T+\mathrm{CM}$ chambers were net dissolving at night $\left(-1.8 \pm 0.3 \mathrm{mmol} \mathrm{CaCO}_{3} \mathrm{~m}^{-2} \mathrm{~h}^{-1}\right)$ and net calcifying during the day $\left(2.4 \pm 0.4 \mathrm{mmol} \mathrm{CaCO}_{3} \mathrm{~m}^{-2} \mathrm{~h}^{-1}\right)$. Overall, $24 \mathrm{~h}$ diel $G_{\text {net }}$ in $T+\mathrm{CM}$ treatments was $0.2 \pm 0.2 \mathrm{mmol} \mathrm{CaCO}_{3} \mathrm{~m}^{-2} \mathrm{~h}^{-1}$, a change which was not significantly different from control chambers $\left(F_{1,15}=0.87\right.$, $p=0.368$ ).

\section{Discussion}

\subsection{The response in coral reef sediment metabolism to seawater warming}

Under control conditions, rates of GPP, $R$, and $G_{\text {net }}$ were similar to those measured in advective benthic chambers simulating equivalent percolation rates (Table 4 ) over $24 \mathrm{~h}$ diel timescales. Furthermore, carbonate sediments were net au- 
Table 4. A comparison of studies which employed the same methodology (advective chamber incubations) under a similar advection rate $\left(\sim 43 \mathrm{~L} \mathrm{~m}^{-2} \mathrm{~d}^{-1}\right)$ and calculated gross primary productivity (GPP: mmol $\left.\mathrm{O}_{2} \mathrm{~m}^{-2} \mathrm{~h}^{-1}\right)$, respiration $\left(R: \mathrm{mmol} \mathrm{O}_{2} \mathrm{~m}^{-2} \mathrm{~h}^{-1}\right)$, the ratio of GPP / $R$, and net calcification $\left(G_{\text {net }}: \mathrm{mmol} \mathrm{CaCO}_{3} \mathrm{~m}^{-2} \mathrm{~h}^{-1}\right)$ under ambient conditions. In this study, data from Cyronak et al. (2013a, b), Cyronak and Eyre (2016), and Trnovsky et al. (2016) were collected in situ at Heron Island, Australia, while data from Lantz et al. (2017a) were collected ex situ in Moorea, French Polynesia.

\begin{tabular}{lrrrr}
\hline Study & $\begin{array}{r}R \\
\left(\mathrm{mmol}_{2} \mathrm{~m}^{-2} \mathrm{~h}^{-1}\right)\end{array}$ & $\begin{array}{r}\mathrm{GPP} \\
\left(\mathrm{mmol} \mathrm{O}_{2} \mathrm{~m}^{-2} \mathrm{~h}^{-1}\right)\end{array}$ & $\mathrm{GPP} / R$ & $\begin{array}{r}G_{\text {net }} \\
\left(\mathrm{mmol} \mathrm{CaCO}_{3} \mathrm{~m}^{-2} \mathrm{~h}^{-1}\right)\end{array}$ \\
\hline This study & $-1.3 \pm 0.5$ & $3.2 \pm 0.4$ & $1.31 \pm 0.1$ & $0.2 \pm 0.2$ \\
Cyronak et al. (2013a) & N/A & N/A & N/A & $0.1 \pm 0.1$ \\
Cyronak et al. (2013b) & N/A & N/A & N/A & $0.2 \pm 0.1$ \\
Cyronak and Eyre (2016) & $-2.5 \pm 0.1$ & $6.3 \pm 0.2$ & $1.27 \pm 0.1$ & $0.4 \pm 0.2$ \\
Trnovsky et al. (2016) & $-2.1 \pm 0.6$ & $5.1 \pm 0.8$ & $1.29 \pm 0.2$ & $0.6 \pm 0.3$ \\
Lantz et al. (2017a) & N/A & N/A & N/A & $0.1 \pm 0.1$ \\
\hline
\end{tabular}

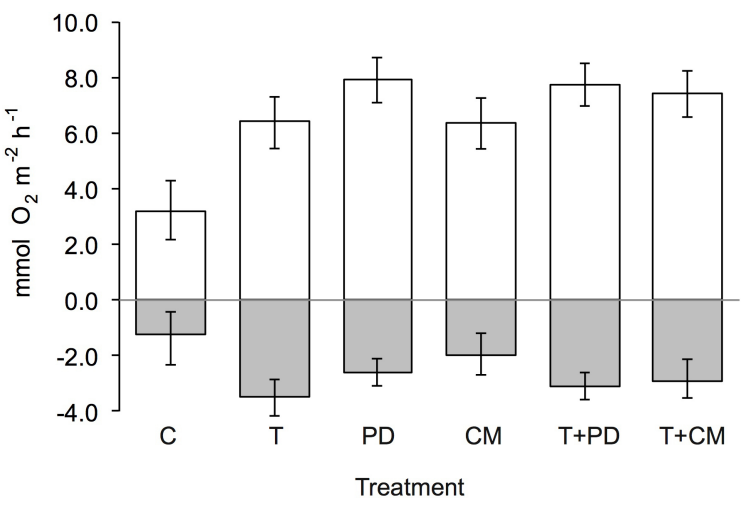

Figure 5. Mean sediment gross primary production (GPP: $\left.\mathrm{mmol} \mathrm{O}_{2} \mathrm{~m}^{-2} \mathrm{~h}^{-1}\right)$ and respiration $\left(R: \mathrm{mmolO}_{2} \mathrm{~m}^{-2} \mathrm{~h}^{-1}\right)$ in response to warming $\left(+2.4{ }^{\circ} \mathrm{C}\right)$ and each OM treatment (phytodetritus and coral mucus). Control $(C ; n=9)$ and warming $(T ; n=7)$ treatments are averaged over all four incubations and the replicate chambers therein. Phytodetritus (PD), coral mucus (CM), and combination $(T+\mathrm{PD}, T+\mathrm{CM})$ treatments are averaged over the two incubations (and replicate chambers therein) in which each respective OM treatment was used $(n=4)$. Average measured rates \pm SD are represented in white for GPP (positive) and grey for $R$ (negative).

totrophic (GPP / $R=1.31 \pm 0.1$ ), similar to previous studies (Eyre et al., 2014). The sediments were net calcifying during the day under all treatment conditions, which was likely due to a combination of light-stimulated biogenic calcification by infaunal organisms (e.g. symbiont-bearing foraminifera: Yamano et al., 2000; or dinoflagellates: Frommlet et al., 2015) and by a photosynthetically mediated increase in porewater aragonite saturation state to a value that would allow for abiotic precipitation $(\Omega>8$; Cohen and Holcomb, 2009). However, the exact organisms and geochemical conditions responsible for the measured net diurnal calcification signal was beyond the scope of this study and should be examined in future work.

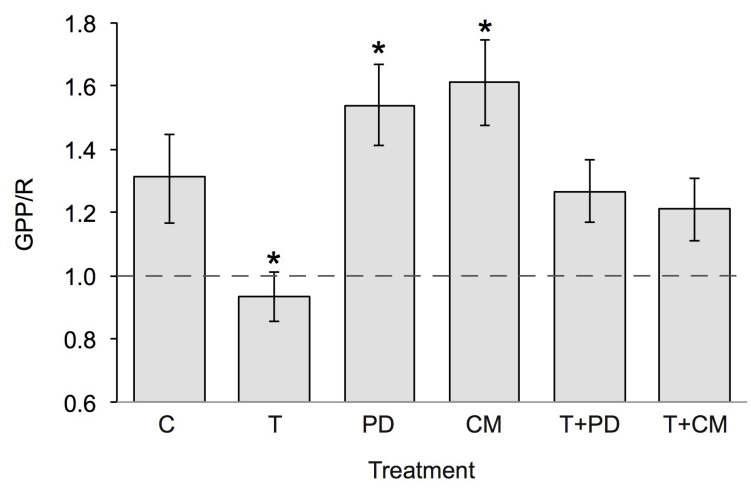

Figure 6. Ratios of sediment gross primary production $(12 \mathrm{~h})$ to respiration $(24 \mathrm{~h}$; GPP $/ R)$ in response to warming $\left(+2.4^{\circ} \mathrm{C}\right)$ and each OM treatment (phytodetritus and coral mucus). Control $(C$; $n=9)$ and warming $(T ; n=7)$ treatments are averaged over all four incubations and the replicate chambers therein, while phytodetritus (PD), coral mucus (CM), and combination $(T+\mathrm{PD}, T+\mathrm{CM})$ treatments are averaged over the two incubations (and replicate chambers therein) in which each respective OM treatment was used $(n=4)$. Dashed grey line represents the divide between net heterotrophy and net autotrophy (GPP / $R=1)$, while the $*$ indicates if the presented value is significantly different the control.

It should also be noted that the daytime incubations in this study were terminated at 16:00, $2 \mathrm{~h}$ before sunset (18:00), to allow time to move each chamber and establish new treatment conditions for the next set of incubations. It is therefore possible that the calculated daytime GPP was slightly overestimated given that the sediments in these final $2 \mathrm{~h}$ before sunset generally exhibit a lower rate of oxygen production relative to the $06: 00$ to $16: 00$ time period due to a reduction in light intensity (Cyronak et al., 2013b). However, a comparison of the mean GPP in control chambers to prior chamber work at the same study site, where incubations lasted until sunset (Cyronak and Eyre, 2016; Table 4), shows that GPP in this study was lower. This suggests that temporal variability in light intensity, temperature, and other abiotic factors 


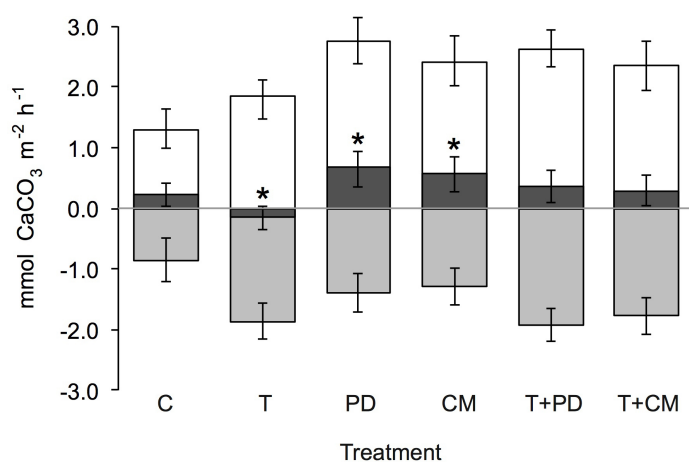

Figure 7. Mean sediment net calcification $\left(G_{\text {net }}\right.$ : $\left.\mathrm{mmol} \mathrm{CaCO}_{3} \mathrm{~m}^{-2} \mathrm{~h}^{-1}\right)$ in response to warming $\left(+2.4^{\circ} \mathrm{C}\right)$ and each $\mathrm{OM}$ treatment (phytodetritus and coral mucus). Control $(C ; n=9)$ and warming $(T ; n=7)$ treatments are averaged over all four incubations and the replicate chambers therein, while phytodetritus (PD), coral mucus (CM), and combination $(T+\mathrm{PD}$, $T+\mathrm{CM}$ ) treatments are averaged over the two incubations (and replicate chambers therein) in which each respective OM treatment was used $(n=4)$. Average measured rates \pm SD are represented in white for light $G_{\text {net }}$ (positive) and grey for dark $G_{\text {net }}$ (negative). Black bars represent the $24 \mathrm{~h}$ diel $G_{\text {net }}$ averaged from light and dark measurements, and the * next to these bars indicates if the value is significantly different from the control.

likely exerts a greater influence on GPP than a $2 \mathrm{~h}$ difference in incubation period.

In our experiments, seawater warming $\left(+2.4 \pm 0.5^{\circ} \mathrm{C}\right)$ was within the projection of the IPCC RCP $8.5(+2.2-$ $2.7^{\circ} \mathrm{C}$ ). Under this elevated seawater temperature, $R$ increased to a greater extent than GPP, shifting the sediments to net heterotrophy (GPP / $R=0.93$ ) over the diel incubation period (Fig. 8). The decrease of GPP / $R$ due to warming can be explained by the relatively lower temperature sensitivity value for GPP $\left(16.1 \pm 2.8 \mathrm{mmol} \mathrm{O}_{2} \mathrm{~m}^{-2} \mathrm{~d}^{-1}{ }^{\circ} \mathrm{C}^{-1}\right)$ compared to $R\left(22.3 \pm 3.8 \mathrm{mmol} \mathrm{O}_{2} \mathrm{~m}^{-2} \mathrm{~d}^{-1}{ }^{\circ} \mathrm{C}^{-1}\right)$. This is further supported by the relatively lower measured $Q_{10}$ value for GPP $(7.3 \pm 1.2)$ compared to $R(10.7 \pm 3.1)$, similar to those measured by Trnovsky et al. (2016) for GPP (3.1-4.1) and $R$ (7.4 to 13.0). It is important to note that the established Arrhenius relationships in the literature suggest that development and growth rates should increase at a rate of $7-$ $12 \%{ }^{\circ} \mathrm{C}^{-1}$ of warming (Clarke, 2003), much lower than the observed 74 and $42 \%$ increase in $R$ and GPP respectively per $1{ }^{\circ} \mathrm{C}$ of warming in this study. However, recent work in the Antarctic by Ashton et al. (2017) on marine benthic assemblages showed that, in some species, the growth rate exhibited a $100 \%$ increase per $1{ }^{\circ} \mathrm{C}$ of warming, yielding $Q_{10}$ values around 1000 . Therefore, while the temperature sensitivity estimates reported in this paper and in Trnovsky et al. (2016) exceed the expected rate for biological reactions and enzyme activity, evidence exists in other benthic marine environments to support the notion that the impact of temperature on biochemical processes may be more complex
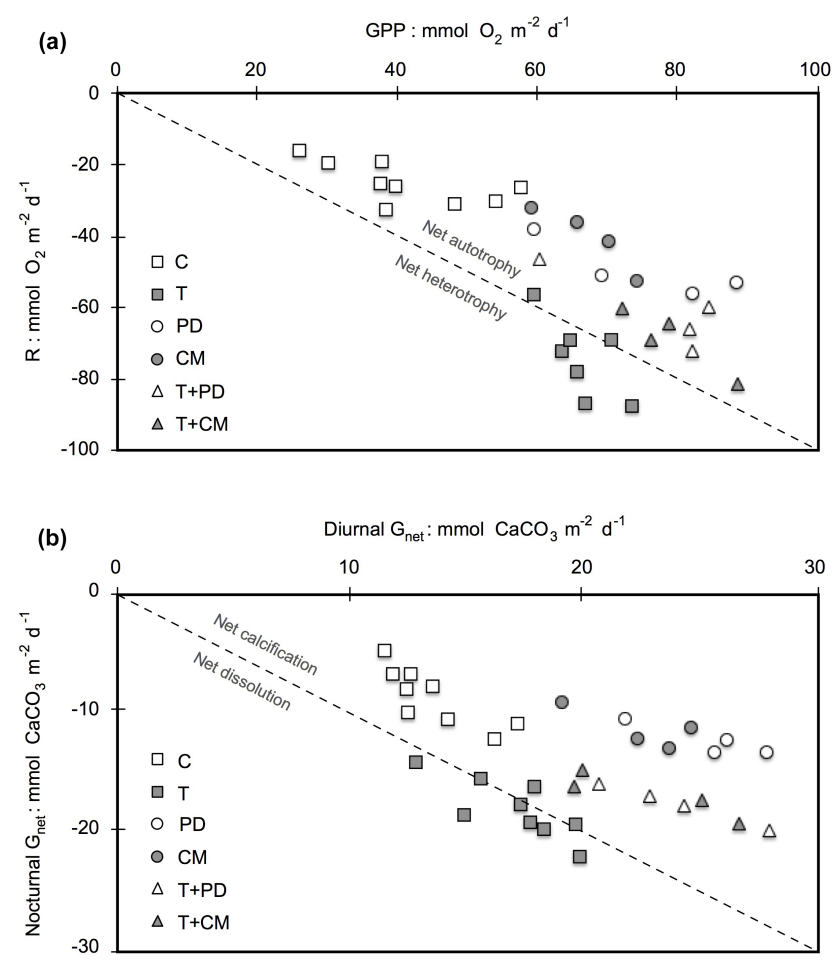

Figure 8. Measured metabolic rates from the control $(C ; n=9)$ and warming $(T ; n=7)$ treatments are displayed from all four incubations and the replicate chambers therein. Phytodetritus (PD), coral mucus (CM), and combination $(T+\mathrm{PD}, T+\mathrm{CM})$ treatments are displayed from the two incubations (and replicate chambers therein) where each respective OM treatment was used $(n=4)$. (a) Respiration $\left(R: \mathrm{mmol} \mathrm{O}_{2} \mathrm{~m}^{-2} \mathrm{~d}^{-1}\right)$ plotted as a function of gross primary production (GPP: $\mathrm{mmol} \mathrm{O}_{2} \mathrm{~m}^{-2} \mathrm{~d}^{-1}$ ). Dashed line represents the divide between net heterotrophy and net autotrophy (GPP/R=1). (b) Dark dissolution (dark G: mmol $\mathrm{CaCO}_{3} \mathrm{~m}^{-2} \mathrm{~d}^{-1}$ ) plotted as a function of daytime calcification (diurnal $\mathrm{G}$ : $\mathrm{mmol} \mathrm{CaCO}_{3} \mathrm{~m}^{-2} \mathrm{~d}^{-1}$ ). Dashed line represents the divide between net calcification and net dissolution $\left(G_{\text {net }}=0\right)$.

than previously thought at the organism level (Ashton et al., 2017).

Overall, the response in GPP / $R$ to temperature agrees with other studies showing that seawater warming preferentially enhances $R$ to a greater degree than GPP in marine sediments (Hancke and Glud, 2004; Weston and Joye, 2005; Tait and Schiel, 2013). The decline in GPP / $R$ in response to warmer seawater temperature may be a product of the differential ranges in activation energies for GPP and $R$ (YvonDurocher et al., 2010), where $R$ exhibits a stronger and more rapid physiological acclimation to warming compared to GPP during short-term temperature variations (Wiencke et al., 1993; Robinson, 2000). The observed $29 \%$ decrease in GPP / $R$ in response to warming leads to a net $109 \%$ decrease in $G_{\text {net }}$ (relative to control chambers), resulting in a transition to net sediment dissolution over the diel incubation period (Fig. 8). This decrease in $G_{\text {net }}$ was most likely due to a 
respiration-driven increase in porewater $p \mathrm{CO}_{2}$ (e.g. Cyronak et al., 2013a), thereby decreasing $\mathrm{pH}$ and the mean porewater aragonite saturation state, as evidenced by decreasing water column levels (mean $\Omega_{\text {arg }}=-0.7$ relative to control chambers). While rising $T$ increases $\Omega_{\text {arg }}$ geochemically, with less than 0.03 units per degree of temperature increase, this effect is negligible and by far outweighed by biologically driven changes in $\Omega_{\mathrm{arg}}$, leading to an overall decrease. In summary, a warming of seawater by $2.4{ }^{\circ} \mathrm{C}$ decreased GPP / $R$ by 0.38 units and $G_{\text {net }}$ by $0.2 \mathrm{mmol} \mathrm{CaCO}_{3} \mathrm{~m}^{-2} \mathrm{~h}^{-1}$ in the permeable calcium carbonate sediments at this study site on Heron Island. The decline in the GPP / $R$ in response to warming implies that a greater fraction of the carbon fixed by autotrophs was remineralised by heterotrophic bacteria and released as $\mathrm{CO}_{2}$, thus compromising the capacity of coral-reefpermeable carbonate sediments to remain net autotrophic at an elevated seawater $T$.

While a decline in marine sediment GPP / $R$ in response to seawater warming has been previously reported in several studies (e.g. Woodwell et al., 1998; Hancke and Glud, 2004; Weston and Joye, 2005; Lopez-Urrutia and Moran, 2007), the response in $G_{\text {net }}$ has only been examined by Trnovsky et al. (2016). It is important to note that these results should not be extrapolated beyond 2100, where SST rises above $+2.4^{\circ} \mathrm{C}$. The $T$ increase simulated in this study $\left(+2.4{ }^{\circ} \mathrm{C}\right)$ was within the optimal temperature range $\left(30.6^{\circ} \mathrm{C}\right)$ of previously reported temperature-metabolism hyperbolic relationships in marine sediments (Yvon-Durocher et al., 2010). Given the nature of hyperbolic relationships a further increase in temperature will eventually have an opposite effect on sediment metabolism (net decrease in GPP and $R$; Weston and Joye, 2005). Thus, the temperature sensitivity reported here should not be extrapolated beyond $2.4^{\circ} \mathrm{C}$.

\subsection{The response in coral reef sediment metabolism to organic matter enrichment}

Increased concentrations of organic matter (OM), analogous to eutrophic conditions on degraded coral reefs, enhanced both GPP and $R$ in the sediment, likely by releasing nitrogen and phosphorus via organic matter degradation. These results agree with prior work, where increased concentrations of OM were quickly aerobically degraded by bacteria within minutes (Maher et al., 2013) to hours (Ferrier-Pages et al., 2000) and enhanced GPP more than $R$ (Glud et al., 2008; Eyre et al., 2008). While some of this OM was likely degraded in the water column, previous experiments (e.g. Wild et al., 2004b) have shown that the high permeability of carbonate sediments permits the transport of OM into the upper centimetres $(1-4 \mathrm{~cm})$ of the sand, where bacterial degradation rates can exceed those of the water column by a factor of 10-12 (Moriarty, 1985; Wilkinson, 1987).

Phytodetritus (PD) and coral mucus (CM) enhanced respiration rates 1.1- and 0.6-fold respectively which was a less pronounced increase in $R$ than the 1.5-fold increase observed by Wild et al. (2004b) using the same Acropora spp. mucus at Heron Island. This difference may be due to the fact their study used almost 3 times more $\mathrm{CM}(\sim 280 \mathrm{~mL})$ per treatment than this study $(94 \mathrm{~mL})$. An increase in GPP / $R$ to 1.7 one day following the deposition of coral spawning material at the same study site (Glud et al., 2008), was similar to the average increase in GPP / $R$ to 1.6 observed under increased OM concentrations in this study. PD enhanced GPP and $R$ to a greater degree than $\mathrm{CM}$, which may be explained by the higher nitrogen content, or more precisely, the lower $\mathrm{C} / \mathrm{N}$ ratio in the former. Particulate organic carbon additions differed by less than $10 \%$ between PD and CM treatments, whereas particulate organic nitrogen addition $(\mathrm{N})$ was almost twice as high by PD compared CM. In general, bacterial communities responsible for the cycling of nutrients in sediments are thought to be nitrogen limited (Eyre et al., 2013). Given the relatively short timescale $(24 \mathrm{~h})$ in which the response in sediment metabolism to OM was measured, we reason that the PD was more rapidly mineralised than CM due to a higher $\mathrm{N}$ content in the added PD (Eyre et al., 2016).

To our knowledge, this is the first experiment to examine the short-term relationship between OM degradation and $G_{\text {net }}$ in coral reef sediments. Our results show that increased concentrations of PD and CM both enhanced $G_{\text {net }}$. Most likely the increase in $G_{\text {net }}$ was a product of the same biogeochemical mechanism influencing $G_{\text {net }}$ under seawater warming, whereby changes in GPP / $R$ modify porewater $\mathrm{pCO}_{2}$ and thus $\Omega_{\mathrm{arg}}$. In the case of OM, a preferential enhancement of GPP over $R$ resulted in an increase in $\Omega_{\text {arg }}$ (mean $\Omega_{\text {arg }}=+0.6$ relative to control chambers) and subsequent increase in $G_{\text {net }}\left(+1.4 \mathrm{mmol} \mathrm{CaCO}_{3} \mathrm{~m}^{-2} \mathrm{~h}^{-1}\right.$ relative to control chambers). While the results presented here are the first to report a positive OM- $G_{\text {net }}$ relationship specifically in permeable calcium carbonate sediments, a similar response has also been observed at ecosystem level in coral reefs (Yeakel et al., 2015), where increased offshore productivity in the Sargasso Sea over the course of several months lead to an increase in community $G_{\text {net }}$ on the adjacent Bermuda coral reef flat. Interestingly, this increase in $G_{\text {net }}$ in Bermuda coincided with a period of net heterotrophy on the reef. The difference in the $G_{\text {net }}-$ GPP / $R$ relationship between the data in this study (OM increased GPP / $R$ and increased $\left.G_{\text {net }}\right)$ and those in Yeakel et al. (2015; OM decreased GPP / $R$ and increased $G_{\text {net }}$ ) may be a result of the timescale of observation. This implies that, should elevated concentrations of OM persist for an extended period of time (weeks to months), the immediate preferentially phototrophically mediated recycling of nutrients, and associated increased GPP / $R$ and $G_{\text {net }}$ in coral reef sediments, may eventually shift to net heterotrophy despite the ability to maintain a positive $G_{\text {net }}$. 


\subsection{The response in coral reef sediment metabolism to a combination of seawater warming and organic matter enrichment}

The combination of seawater warming and increased concentrations of OM, for both PD and CM, enhanced GPP $(+17 \%$ relative to the temperature alone) and $R(+11 \%$ relative to temperature alone) but countered the effect on GPP / $R$ and $G_{\text {net }}$ (no significant difference from the control). Given the effect of each of these treatments ( $T$ and OM) independently on sediment GPP / $R$ and $G_{\text {net }}$, this result is not surprising. A decrease in GPP / $R$ and $G_{\text {net }}$ due to warming was countered by an increase in GPP / $R$ and $G_{\text {net }}$ due to an increased concentration of OM.

This finding raises questions within the context of each treatment, as mean SST on coral reefs will continuously rise from now until beyond 2100, consistently affecting sediment metabolism. However, organic matter enrichment of permeable coral reef carbonate sediments is also likely to gradually increase due to enhanced algal production from elevated nutrients (Furnas et al., 2005), elevated terrestrial input of OM (Diaz-Ortega and Hernandez-Delgado, 2014) and enhanced mucus production due to enhanced terrestrial sedimentation (Alongi and McKinnon, 2005). As discussed above this longterm enrichment with OM will most likely make coral reef sediments more heterotrophic (and not more autotrophic as in this short-term study). However the subsequent response in $G_{\text {net }}$ over longer timescales is less clear, as some work has shown that the degradation of organic matter can enhance sediment dissolution (Andersson, 2015), whereas other work (e.g. Yeakel et al., 2015) has shown that community calcification may actually increase. Therefore, combined with an increase in $T$, the effect of long-term enrichment of OM on GPP / $R$ is likely to be additive (decrease GPP / $R$ ), but the long-term response in $G_{\text {net }}$ still needs further examination.

Similarly, the effect of other, more persistent products of eutrophication, namely dissolved inorganic nutrients (DIN: $\mathrm{NH}_{4}^{+}, \mathrm{NO}_{3}^{-}, \mathrm{PO}_{4}^{3-}$ ), on coral reef sediment GPP / $R$ and $G_{\text {net }}$ have yet to be studied and may become more frequent and persistent as coastal land use changes continue to facilitate the increased runoff of fertilisers (Koop et al., 2001). Consequently, the results presented here provide an estimation of the future short-term response in coral reef sediment GPP / $R$ and $G_{\text {net }}$ to warming $\left(+2.4{ }^{\circ} \mathrm{C}\right)$ and eutrophication (PD and $\mathrm{CM}$ ), but by no means have explored other potential warming- and eutrophication-mediated perturbations that continue to threaten coral reef ecosystems. Future work should consider varying durations (e.g. $>24 \mathrm{~h}$ ) and forms of eutrophication (e.g. DIN) as well as a range of $T$, both within and beyond reported optimal ranges $\left(>2.4^{\circ} \mathrm{C}\right)$, to better constrain our understanding of the potential feedback responses in coral reef sediment GPP / $R$ and $G_{\text {net. }}$.

\section{Conclusions}

This study suggests that seawater warming will shift GPP / $R$ and $G_{\text {net }}$ in permeable calcium carbonate coral reef sediments to a state of net heterotrophy and net dissolution respectively by the year 2100 . In contrast, short-term eutrophication, and the subsequent production of $\mathrm{OM}$ in the form of phytodetritus and coral mucus, could enhance sediment GPP / $R$ and $G_{\text {net }}$. The combined effect of seawater warming and increased concentrations of OM may additively enhance sediment GPP and $R$, but the net effects on GPP / $R$ and $G_{\text {net }}$ will likely counter one another on relatively short timescales of days. The future response in the net flux behaviour of $\mathrm{CO}_{2}$ and $\mathrm{O}_{2}$ in the coral reef sediment environment, and the consequent rate of carbon sequestration into the sediments, will likely depend on the relative frequency and duration of each perturbation. The effects of OM (e.g. phytoplankton growth, reef-wide mucus secretion) on sediment metabolism generally persist temporarily (days to weeks) relative to global warming, a constant process which will continue to occur throughout this century and beyond. Provided this ecological context and the findings from this study, we propose that increased concentrations of $\mathrm{OM}$, in the form of phytodetritus and coral mucus, will increase $G_{\text {net }}$ and GPP / $R$ in the sediment on relatively short timescales. However, once seawater temperature on coral reefs rises $2.4^{\circ} \mathrm{C}$ above the present-day mean, the immediate effect of OM on sediment metabolism will be compromised by a warming-mediated net decrease in $G_{\text {net }}$ and GPP / $R$, thereby limiting the ability of permeable calcium carbonate sediments on coral reefs to accumulate calcium carbonate.

Data availability. Archived data are available for access on PANGAEA (https://doi.org/10.1594/PANGAEA.883559, Lantz et al., 2017b).

Competing interests. The authors declare that they have no conflict of interest.

Acknowledgements. We would like to thank Jacob Yeo for his assistance in the field. This research was funded by ARC Discovery Grant DP150102092 and conducted under GBRMPA permit number G16/38438.1.

Edited by: Carol Robinson

Reviewed by: Angelos Hannides and one anonymous referee 


\section{References}

Alongi, D. M. and McKinnon, A. D.: The cycling and fate of terrestrially-derived sediments and nutrients in the coastal zone of the Great Barrier Reef shelf, Mar. Pollut. Bull., 51, 239-252, 2005.

Andersson, A. J.: A fundamental paradigm for coral reef carbonate sediment dissolution, Front. Mar. Sci., 2, 52, https://doi.org/10.3389/fmars.2015.00052, 2015.

Ashton, G. V., Morley, S. A., Barnes, D. K. A., Clark, M. S., and Peck, L. S.: Warming by $1^{\circ} \mathrm{C}$ Drives Species and Assemblage Level Responses in Antarctica's Marine Shallows, Curr. Biol., 2698-2705, https://doi.org/10.1016/j.cub.2017.07.048, 2017.

Atkinson, M. J.: Biogeochemistry of nutrients, in Coral Reefs: An Ecosystem in Transition, Springer Netherlands, Dordrecht, 199206, 2011

Bahr, K. D., Jokiel, P. L., and Rodgers, K. S.: Influence of solar irradiance on underwater temperature recorded by temperature loggers on coral reefs, Limnol. Oceanogr.-Meth., 14, 338-342, https://doi.org/10.1002/lom3.10093, 2016.

Bell, P. R. F.: Eutrophication and coral reefs-some examples in the Great Barrier Reef lagoon, Water Res., 26, 553-568, https://doi.org/10.1016/0043-1354(92)90228-V, 1992.

Bernacchi, C. J., Singsaas, E. L., Pimentel, C., Portis, A. R. R., and Long, S. P.: Improved temperature response functions for models of Rubisco-limited photosynthesis, Plant Cell Environ., 24, 253 259, https://doi.org/10.1046/j.1365-3040.2001.00668.x, 2001.

Chanson, M. and Millero, F. J.: Effect of filtration on the total alkalinity of open-ocean seawater, Limnol. Oceanogr.-Meth., 5, 293295, https://doi.org/10.4319/lom.2007.5.293, 2007.

Clarke, A.: Costs and consequences of evolutionary temperature adaptation, Trends Ecol. Evol., 18, 573-581, https://doi.org/10.1016/j.tree.2003.08.007, 2003.

Cohen, A. L. and Holcomb, M.: Why corals care about ocean acidification Uncovering the mechanism, Oceanography, 22, 118127, https://doi.org/10.5670/oceanog.2009.102, 2009.

Cyronak, T., Santos, I. R., and Eyre, B. D.: Permeable coral reef sediment dissolution driven by elevated $\mathrm{pCO} 2$ and pore water advection, Geophys. Res. Lett., 40, 4876-4881, https://doi.org/10.1002/grl.50948, 2013a.

Cyronak, T., Santos, I. R., McMahon, A., and Eyre, B. D.: Carbon cycling hysteresis in permeable carbonate sands over a diel cycle: Implications for ocean acidification, Limnol. Oceanogr., 58, 131-143, https://doi.org/10.4319/lo.2013.58.1.0131, 2013 b.

Cyronak, T. and Eyre, B. D.: The synergistic effects of ocean acidification and organic metabolism on calcium carbonate $(\mathrm{CaCO} 3)$ dissolution in coral reef sediments, Mar. Chem., 183, 1-12, https://doi.org/10.1016/j.marchem.2016.05.001, 2016.

Díaz-ortega, G. and Hernández-Delgado, E. a: Unsustainable LandBased Source Pollution in a Climate of Change: A Roadblock to the Conservation and Recovery of Elkhorn Coral Acropora palmata (Lamarck 1816), Nat. Resour., 5, 561-581, https://doi.org/10.4236/nr.2014.510050, 2014.

Dickson, A. G. and Millero, F. J.: A comparison of the equilibrium constants for the dissociation of carbonic acid in seawater media, Deep-Sea Res. Pt. I, 34, 1733-1743, https://doi.org/10.1016/0198-0149(87)90021-5, 1987.

Dickson, A. G., Sabine, C. L., and Christian, J. R.: Guide to best practices for ocean $\mathrm{CO} 2$ measurements, North Pacific Marine Science Organization, 2007.
Ducklow, H. W. and Mitchell, R.: Composition of mucus released by coral reef coelenterates, Limnol. Oceanogr., 24, 706-714, https://doi.org/10.4319/lo.1979.24.4.0706, 1979.

Edinger, E. N., Jompa, J., Limmon, G. V, Widjatmoko, W., and Risk, M. J.: Reef degradation and coral biodiversity in Indonesia: Effects of land-based pollution, destructive fishing practices and changes over time, Mar. Pollut. Bull., 36, 617-630, https://doi.org/10.1016/S0025-326X(98)00047-2, 1998.

Eyre, B. D., Glud, R. N., and Patten, N.: Mass coral spawning: A natural large-scale nutrient addition experiment, Limnol. Oceanogr., 53, 997-1013, https://doi.org/10.4319/lo.2008.53.3.0997, 2008.

Eyre, B. D., Ferguson, A. J. P., Webb, A., Maher, D., and Oakes, J. M.: Metabolism of different benthic habitats and their contribution to the carbon budget of a shallow oligotrophic sub-tropical coastal system (southern Moreton Bay, Australia), Biogeochemistry, 102, 87-110, https://doi.org/10.1007/s10533-010-9424-7, 2011.

Eyre, B. D., Santos, I. R., and Maher, D. T.: Seasonal, daily and diel $\mathrm{N} 2$ effluxes in permeable carbonate sediments, Biogeosciences, 10, 2601-2615, https://doi.org/10.5194/bg-10-2601-2013, 2013.

Eyre, B. D., Andersson, A. J., and Cyronak, T.: Benthic coral reef calcium carbonate dissolution in an acidifying ocean, Nature Climate Change, 4, 969-976, https://doi.org/10.1038/nclimate2380, 2014.

Eyre, B. D., Oakes, J. M., and Middelburg, J. J.: Fate of microphytobenthos nitrogen in subtropical subtidal sediments: A $15 \mathrm{~N}$ pulse-chase study, Limnol. Oceanogr., 61, 2108-2121, https://doi.org/10.1002/lno.10356, 2016.

Fabricius, K. E.: Effects of terrestrial runoff on the ecology of corals and coral reefs: Review and synthesis, Mar. Pollut. Bull., 50, 125-146, https://doi.org/10.1016/j.marpolbul.2004.11.028, 2005.

Ferguson, A., Eyre, B., and Gay, J.: Organic matter and benthic metabolism in euphotic sediments along shallow sub-tropical estuaries, northern New South Wales, Australia, Aquat. Microb. Ecol., 33, 137-154, https://doi.org/10.3354/ame033137, 2003.

Ferrier-Pagès, C., Leclercq, N., Jaubert, J., and Pelegrí, S. P.: Enhancement of pico- and nanoplankton growth by coral exudates, Aquat. Microb. Ecol., 21, 203-209, https://doi.org/10.3354/ame021203, 2000.

Frommlet, J. C., Sousa, M. L., Alves, A., Vieira, S. I., Suggett, D. J., and Serôdio, J.: Coral symbiotic algae calcify ex hospite in partnership with bacteria, P. Natl. Acad. Sci. USA, 112, 61586163, https://doi.org/10.1073/pnas.1420991112, 2015.

Furnas, M., Mitchell, A., Skuza, M., and Brodie, J.: In the other $90 \%$ : Phytoplankton responses to enhanced nutrient availability in the Great Barrier Reef Lagoon, Mar. Pollut. Bull., 51, 253265, 2005.

Glud, R. N., Eyre, B. D., and Patten, N.: Biogeochemical responses to mass coral spawning at the Great Barrier Reef: Effects on respiration and primary production, Limnol. Oceanogr., 53, 10141024, https://doi.org/10.4319/lo.2008.53.3.1014, 2008.

Grigg, R. W.: Coral reefs in an urban embayment in Hawaii: a complex case history controlled by natural and anthropogenic stress, Coral Reefs, 14, 253-266, https://doi.org/10.1007/BF00334349, 1995. 
Guillard, R. R. L.: Culture of Phytoplankton for Feeding Marine Invertebrates, in Culture of Marine Invertebrate Animals, Springer US, Boston, MA, 29-60, 1975.

Hancke, K. and Glud, R. N.: Temperature effects on respiration and photosynthesis in three diatom-dominated benthic communities, Aquat. Microb. Ecol., 37, 265-281, https://doi.org/10.3354/ame037265, 2004.

Hancke, K., Sorrell, B. K., Chresten Lund-Hansen, L., Larsen, M., Hancke, T., and Glud, R. N.: Effects of temperature and irradiance on a benthic microalgae community: A combined two-dimensional oxygen and fluorescence imaging approach, Limnol. Oceanogr., 59, 1599-1611, https://doi.org/10.4319/lo.2014.59.5.1599, 2014.

Huettel, M. and Gust, G.: Solute release mechanisms from confined sediment cores in stirred benthic chambers and flume flows, Mar. Ecol.-Prog. Ser., 82, 187-197, https://doi.org/10.3354/meps082187, 1992.

IPCC: Summary for policymakers, Climate Change 2013: The Physical Science Basis Contribution of Working Group I to the Fifth Assessment Report of the Intergovernmental Panel on Climate Change, Cambridge University Press, Cambridge, United Kingdom and New York, NY USA, 2013.

Johnson, M. D. and Carpenter, R. C.: Ocean acidification and warming decrease calcification in the crustose coralline alga Hydrolithon onkodes and increase susceptibility to grazing, J. Exp. Mar. Biol. Ecol., 434-435, 94-101, https://doi.org/10.1016/j.jembe.2012.08.005, 2012.

Koop, K., Booth, D., Broadbent, A., Brodie, J., Bucher, D., Capone, D., Coll, J., Dennison, W., Erdmann, M., Harrison, P., HoeghGuldberg, O., Hutchings, P., Jones, G. B., Larkum, A. W. D., O’Neil, J., Steven, A., Tentori, E., Ward, S., Williamson, J., and Yellowlees, D.: ENCORE: The effect of nutrient enrichment on coral reefs. Synthesis of results and conclusions, Mar. Pollut. Bull., 42, 91-120, https://doi.org/10.1016/S0025326X(00)00181-8, 2001.

Lantz, C. A., Carpenter, R. C., and Edmunds, P. J.: Calcium carbonate $(\mathrm{CaCO} 3)$ sediment dissolution under elevated concentrations of carbon dioxide (CO2) and nitrate (NO3-), J. Exp. Mar. Biol. Ecol., 495, 48-56, https://doi.org/10.1016/j.jembe.2017.05.014, 2017.

Lantz, C. A., Schulz, K. G., Stoltenberg, L., and Eyre, B. D.: Gross primary production, respiration, and net calcification in coral reef sediments of Heron Island Lagoon, Australia, determined by in situ benthic chamber incubations, https://doi.org/10.1594/PANGAEA.883559, 2017.

Lavigne, H. and Gattuso, J.P.: Package "seacarb';: seawater carbonate chemistry with R, v. 2.4. 8, edited by: R Development Core Team, available at: see https://cran.r-project.org/web/packages/ seacarb/index.html (last access: 1 November 2016), 2013.

Lee, K. and Millero, F. J.: Thermodynamic studies of the carbonate system in seawater, Deep-Sea Res. Pt. I, 42, 2035-2061, https://doi.org/10.1016/0967-0637(95)00077-1, 1995.

Levitus, S., Antonov, J. I., Boyer, T. P., and Stephens, C.: Warming of the World Ocean, Science, 287, 2225-2229, https://doi.org/10.1126/science.287.5461.2225, 2000.

López-Urrutia, Á. and Morán, X. A. G.: Resource limitation of bacterial production distorts the temperature dependence of oceanic carbon cycling, Ecology, 88, 817-822, https://doi.org/10.1890/06-1641, 2007.
Maher, D. T., Santos, I. R., Leuven, J. R. F. W., Oakes, J. M., Erler, D. V., Carvalho, M. C., and Eyre, B. D.: Novel Use of Cavity Ring-down Spectroscopy to Investigate Aquatic Carbon Cycling from Microbial to Ecosystem Scales, Environ. Sci. Technol., 47, 12938-12945, https://doi.org/10.1021/es4027776, 2013.

Mallela, J. and Perry, C. T.: Calcium carbonate budgets for two coral reefs affected by different terrestrial runoff regimes, Rio Bueno, Jamaica, Coral Reefs, 26, 129-145, https://doi.org/10.1007/s00338-006-0169-7, 2007.

Mehrbach, C., Culberson, C. H., Hawley, J. E., and Pytkowicx, R. M.: Measurement of the apparent dissociation constatns of carbonic acid in seawater at atmospheric pressure, Limnol. Oceanogr., 18, 897-907, https://doi.org/10.4319/lo.1973.18.6.0897, 1973.

Middelburg, J. J., Soetaert, K., and Herman, P. M. J.: Empirical relationships for use in global diagenetic models, Deep-Sea Res. Pt. I, 44, 327-344, https://doi.org/10.1016/S0967-0637(96)00101X, 1997.

Moriarty, D. J. W., Pollard, P. C., and Hunt, W. G.: Temporal and spatial variation in bacterial production in the water column over a coral reef, Mar. Biol., 85, 285-292, https://doi.org/10.1007/BF00393249, 1985.

Muehllehner, N., Langdon, C., Venti, A., and Kadko, D.: Dynamics of carbonate chemistry, production, and calcification of the Florida Reef Tract (2009-2010): Evidence for seasonal dissolution, Global Biogeochem. Cy., 30, 661-688, https://doi.org/10.1002/2015GB005327, 2016.

Odum, H. T. and Odum, E. P.: Trophic Structure and Productivity of a Windward Coral Reef Community on Eniwetok Atoll, Ecol Monogr., 25, 291-320, https://doi.org/10.2307/1943285, 1955.

Orlando, J. L. and Yee, S. H.: Linking Terrigenous Sediment Delivery to Declines in Coral Reef Ecosystem Services, Estuar. Coast., 40, 359-375, https://doi.org/10.1007/s12237-016-0167-0, 2017.

Pandolfi, J. M., Connolly, S. R., Marshall, D. J., and Cohen, A. L.: Projecting coral reef futures under global warming and ocean acidification, Science, 333, 418-422, https://doi.org/10.1126/science.1204794, 2011.

Rabalais, N. N., Turner, R. E., Díaz, R. J., and Justić, D.: Global change and eutrophication of coastal waters, ICES J. Mar. Sci., 66, 1528-1537, https://doi.org/10.1093/icesjms/fsp047, 2009.

Rabouille, C., Mackenzie, F. T., and Ver, L. M.: Influence of the human perturbation on carbon, nitrogen, and oxygen biogeochemical cycles in the global coastal ocean, Geochim. Cosmochim. Ac., 65, 3615-3641, https://doi.org/10.1016/S00167037(01)00760-8, 2001.

Robinson, C.: Plankton gross production and respiration in the shallow water hydrothermal systems of Miles, Aegean Sea, J. Plankton Res., 22, 887-906, https://doi.org/10.1093/plankt/22.5.887, 2000.

Roelfsema, R. T. C. M. and Roelfsema, R. T. C. M.: Spatial distribution of benthic microalgae on coral reefs determined by remote sensing, Coral Reefs, 21, 264-274, https://doi.org/10.1007/s00338-002-0242-9, 2002.

Salmond, J., Loder, J., Roelfsema, C., Host, R., and Passenger, J.: Reef Check Australia 2015 Heron Reef Health Report, Reef Check Foundation Ltd., Brisbane, 2015.

Shaw, E. C., Carpenter, R. C., Lantz, C. A., and Edmunds, P. J.: Intraspecific variability in the response to ocean warming and acid- 
ification in the scleractinian coral Acropora pulchra, Mar. Biol., 163, 210, https://doi.org/10.1007/s00227-016-2986-8, 2016.

Tait, L. W. and Schiel, D. R.: Impacts of Temperature on Primary Productivity and Respiration in Naturally Structured Macroalgal Assemblages, PLoS One, 8, e74413, https://doi.org/10.1371/journal.pone.0074413, 2013.

Trnovsky, D., Stoltenberg, L., Cyronak, T., and Eyre, B.D.: Antagonistic Effects of Ocean Acidification and Rising Sea Surface Temperature on the Dissolution of Coral Reef Carbonate Sediments, Front. Mar. Sci., 3, 211, https://doi.org/10.3389/fmars.2016.00211, 2016.

Weston, N. B. and Joye, S. B.: Temperature-driven decoupling of key phases of organic matter degradation in marine sediments, P. Natl. Acad. Sci. USA, 102, 17036-17040, https://doi.org/10.1073/pnas.0508798102, 2005.

Wiencke, C., Rahmel, J., Karsten, U., Weykam, G. and Kirst, G. O.: Photosynthesis of marine macroalgae from Antarctica: Light and temperature requirements, Bot. Act., 106, 78-87, https://doi.org/10.1111/j.1438-8677.1993.tb00341.x, 1993.

Wild, C., Huettel, M., Klueter, A., Kremb, S. G., Rasheed, M. Y. M., and Jørgensen, B. B.: Coral mucus functions as an energy carrier and particle trap in the reef ecosystem, Nature, 428, 6670, https://doi.org/10.1038/nature02344, 2004a.

Wild, C., Rasheed, M., Werner, U., Franke, U., Johnstone, R., and Huettel, M.: Degradation and mineralization of coral mucus in reef environments, Mar. Ecol.-Prog. Ser., 267, 159-171, https://doi.org/10.3354/meps267159, 2004b.
Wild, C., Rasheed, M., Jantzen, C., Cook, P., Struck, U., Huettel, M., and Boetius, A.: Benthic metabolism and degradation of natural particulate organic matter in carbonate and silicate reef sands of the northern Red Sea, Mar. Ecol.-Prog. Ser., 298, 6978, https://doi.org/10.3354/meps298069, 2005.

Wilkinson, C. R.: Microbial ecology on a coral reef, Search, 18, 31-33, 1987.

Woodwell, G. M., Mackenzie, F. T., Houghton, R. A., Apps, M., Gorham, E., and Davidson, E.: Biotic feedbacks in the warming of the earth, Clim. Change, 40, 495-518, https://doi.org/10.1023/A:1005345429236, 1998.

Yamano, H., Miyajima, T., and Koike, I.: Importance of foraminifera for the formation and maintenance of a coral sand cay: Green Island, Australia, Coral Reefs, 19, 51-58, https://doi.org/10.1007/s003380050226, 2000.

Yeakel, K. L., Andersson, A. J., Bates, N. R., Noyes, T. J., Collins, A., and Garley, R.: Shifts in coral reef biogeochemistry and resulting acidification linked to offshore productivity. P. Natl. Acad. Sci. USA, 112, 14512-14517, https://doi.org/10.1073/pnas.1507021112, 2015.

Yvon-Durocher, G., Jones, J. I., Trimmer, M., Woodward, G., and Montoya, J. M.: Warming alters the metabolic balance of ecosystems, Philos. T. R. Soc. B, 365, 2117-2126, https://doi.org/10.1098/rstb.2010.0038, 2010. 